\title{
Consumo turístico durante o Camiño de Santiago. 0 Camiño Nós como ruta alternativa de peregrinación a Santiago
}

\author{
Noelia Araújo Vila*a / José Antonio Fraiz Brea ${ }^{b}$ / Diego Rodríguez-Toubes Muñiz \\ a Universidade de Vigo, Departamento de Economía Financeira e Contabilidade, Campus Universitario As Lagoas s/n, 32004 \\ Ourense, España \\ b Universidade de Vigo, Departamento de Organización de Empresas e Márketing, Campus Universitario As Lagoas s/n, \\ 32004 Ourense, España
}

Recibido: 5 de febreiro de 2021 / Aceptado: 6 de maio de 2021

\begin{abstract}
Resumo
O Camiño de Santiago a través das súas diferentes rutas continúa a ser un dos principais reclamos turísticos de Galicia. Xa sexa por motivación relixiosa ou doutro tipo, cada ano seguen chegando a Santiago gran número de peregrinos, converténdose o Camiño nunha grande oportunidade turística para os concellos que están ao seu paso. Este estudo analiza o consumo turístico durante a realización do Camiño e as expectativas antes da súa realización e, de modo secundario, o coñecemento de novas rutas para chegar a Santiago que van máis aló das máis convencionais, en concreto o Camiño Nós, podendo así obter unha maior vertebración do territorio galego como parte da experiencia do Camiño. Óptase por unha investigación cuantitativa vía enquisa, cunha mostra de 198 individuos. Os resultados indican que a principal motivación para facer o Camiño é o lecer, e que en función da variable idade son tres os grupos diferenciados de consumo. Ademais, a pesar da actual situación de pandemia mundial, unha porcentaxe significativa da mostra realizou o Camiño no último ano (o 17,3\%).
\end{abstract}

\section{Palabras clave}

Consumo turístico; Camiño de Santiago; Camiño Nós; motivación; turismo relixioso.

\section{Tourist spending along the Way of Saint James. The Nós Way as an alternative pilgrimage route to Santiago}

\begin{abstract}
Thanks to its different routes, the Way of Saint James continues to be one of the main tourist attractions in Galicia. Whether for religious or other reasons, every year a large number of pilgrims continue to arrive in Santiago de Compostela, providing great tourist opportunities for the municipalities that are located along the Way. This study analyses the current motivations that lead tourists to undertake the Saint James Way and the weight of their spending patterns during this experience. The insight of the "Nós" Way is assessed, a different route to Santiago from the traditional ones, as a new reality of the Way that can provide greater knowledge of the Galician territory. Quantitative research was chosen using a survey of 198 participants. The results show that the main motivation for following the Way is leisure, and that the age variable divides consumers into three distinct groups. Furthermore, despite the current global pandemic situation, a significant percentage of the sample completed the Way in 2020 (17.3\%).
\end{abstract}

\section{Keywords}

Tourist consumption; Way of Saint James; the Nós Way; motivation; religious tourism.

JEL Codes: L83.

\footnotetext{
* N. Araújo: naraujo@uvigo.es (autora para correspondencia), J. A. Fraiz: jafraiz@uvigo.es, D. Rodríguez-Toubes: drtoubes@uvigo.es
} 


\section{Introdución}

Na actualidade, as peregrinacións, fenómeno con gran número de adeptos séculos atrás, volven estar nun momento de apoxeo. Estase ante un fenómeno relixioso, cultural, cognitivo e socioeconómico con gran repercusión mundial (Rejman, Maziarz, Kwiatkowski e Haliniarz, 2016). Estamos a falar do denominado turismo relixioso, xa que o fin deste tipo de turismo é visitar algún santuario, sitio con importancia relixiosa ou incluso algún evento de carácter relixioso. 0 que non está tan claro é a motivación que leva a cada turista a emprender este tipo de turismo, podendo ser relixiosa ou doutro tipo, por exemplo espiritual ou cultural. Estase así ante un tipo de turismo en continua transformación, tanto pola motivación que leva á súa práctica como polo tipo de produto consumido durante a viaxe. 0 método de viaxe, os lugares visitados durante esta experiencia ou o aloxamento elixido conforman un produto variado e máis amplo que a peregrinación en si. 0 peregrino, independentemente da súa motivación para emprender esta viaxe, busca incentivos adicionais que complementen a súa motivación principal, gozando dos recursos que vai atopando ao longo da súa peregrinación.

Como exemplo de peregrinación mundial recoñecida está o Camiño de Santiago, un armazón de itinerarios de peregrinación europeos que converxen en Santiago de Compostela, no noroeste de España. É esta unha ruta de peregrinación que apareceu na Idade Media, con períodos de abandono posteriores e cun grande apoxeo na actualidade. Tamén houbo un rexurdimento do número de peregrinos como resultado dun esforzo pola proliferación de asociacións e estudos xacobeos (Lois González, 2013). Os peregrinos viaxan a Santiago de Compostela a pé ou por outros medios de transporte que requiran o uso das súas propias forzas. A peregrinación combina a procura de experiencias insólitas, a viaxe lenta, a contemplación da paisaxe e natureza (Granero, Ruiz e García, 2005), aprender sobre a historia e a cultura e coñecer xente nova. O Camiño de Santiago convértese deste xeito nun bo exemplo de como a fe é unha boa forma de explorar a peregrinación, con máis de 1.200 anos de historia. A popularidade da peregrinación a pé a Santiago de Compostela, no noroeste de España, a miúdo enténdese como un novo tipo de turismo espiritual en lugar dun renacemento da práctica relixiosa (Moulin-Stożek, 2019).

A peregrinación a Santiago de Compostela está unida ás súas diferentes rutas, aos monumentos e á paisaxe. Esta ruta foi declarada como o primeiro Itinerario Cultural Europeo polo Consello de Europa en 1987, e en 1993 foi incluída na Lista de Patrimonio Mundial da Organización das Nacións Unidas para a Educación, a Ciencia e a Cultura (UNESCO). Non todas as rutas forman parte deste recoñecemento, máis ben o Camiño Francés (Matín-Duque, 2017; Sánchez-Carretero, 2012). Pero, ademais desta ruta, teñen amplo recoñecemento a Vía da Prata, o Camiño do Norte, o Camiño Portugués ou o Camiño Inglés, por mencionar algunhas. Con todo, non se limita á Península Ibérica: a rede do Camiño comeza na porta da casa do peregrino, por iso noutros países de Europa atópanse os sinais da cuncha e a frecha amarela (Mróz, Mróz e Krogmann, 2019).

O presente traballo céntrase, por tanto, no Camiño de Santiago. Por unha banda, no consumo turístico durante a realización do Camiño e tamén polas expectativas antes da súa realización, así como o coñecemento de novas rutas para chegar a Santiago, que van máis aló das máis convencionais, podendo así obter unha maior vertebración do territorio galego como parte da experiencia do Camiño; e por outra banda, no coñecemento dunha variante da Vía da Prata no seu tramo final, o Camiño Nós, ruta levada a cabo en xuño de 1926 polos membros da Xeración Nós, Javier Pardo, Ramón Otero Pedrayo, Vicente Risco, Lois Feixó, Monxardín e Antón Sánchez, desde Ourense a Santiago de Compostela.

Preténdese ter un maior coñecemento das motivacións actuais que levan aos turistas a emprender esta experiencia e o peso que ten o turismo neste proceso, así como o coñecemento de novas rutas para chegar a Santiago. Para iso, realízase, en primeiro lugar, unha revisión teórica dos conceptos de peregrinación e turismo relixioso e das motivacións que impulsan a este tipo de turistas para, a continuación, presentar o Camiño Nós. Como metodoloxía de traballo optouse por unha investigación cuantitativa vía enquisa, cunha mostraxe de bóla de neve. Finalmente, preséntanse os principais resultados obtidos e as conclusións desta investigación. 


\section{Revisión teórica}

\subsection{Camiño de Santiago. Relixión e turismo}

A relixión ten un papel clave na vida de moitas persoas, chegando a influír en factores como as prácticas turísticas, a elección do destino e a motivación para visitalo (Collins-Kreiner e Kliot, 2000). Xorde así o turismo relixioso, entendido como aquel tipo de turismo cuxos participantes están motivados total ou parcialmente por causas relixiosas (Kim, Kim e King, 2020; McKelvie, 2005; Raj e Griffin, 2015; Rinschede, 1990, 1992). Para Shinde (2010, p. 523) "o turismo relixioso é un termo amplamente utilizado en teoría e práctica para referirse aos patróns de viaxe contemporáneos aos lugares de peregrinación". Segundo Vukonić (1996), defínese como o conxunto de lugares espirituais e servizos asociados que foron visitados durante séculos e por razóns relixiosas. Estes lugares son xeralmente un sitio sacro, un sitio de peregrinación ou un sitio de patrimonio relixioso. Combínanse así dous extremos opostos, o sacro e o profano, como se reflicte na dicotomía peregrinación-turismo (Nolan e Nolan, 1992; Smith, 1992). Probablemente, este fenómeno sexa tan antigo como a propia relixión e, por tanto, un dos tipos de turismos máis lonxevos. Non se limita só ao cristianismo, senón a calquera historia relixiosa (Lanczkowski, 1982). Roussel (1972) sinala que este fenómeno xa se deu en sociedades tribais de Europa, Australia, América e Asia en tempos prehistóricos, onde as pinturas das covas equivalían ás actuais catedrais.

A peregrinación, como un movemento cara a un centro sacro destinado a estar exposto á presenza de Deus (Coleman e Elsner, 1995), gañou maior atención académica desde finais da década de 1980 (Eade, 2016; Finca, Rego e Santos, 2010); mostra disto é a expansión do número de estudos que se manifesta en diversos campos da peregrinación: turismo relixioso, materialidades, raza, xénero, etnia, patrimonio, turismo escuro, tecnoloxías e novos medios, etcétera.

Diversos autores abordaron e investigaron o turismo relixioso, sendo varias as propostas para a súa clasificación. Segundo Nolan e Nolan (1992), son tres as categorías de atractivos turísticos relixiosos: (1) santuarios de peregrinación, definidos como lugares que serven como obxectivos de viaxes por motivos relixiosos, partindo máis alá da propia residencia (sería o caso dos diferentes Camiños de Santiago); (2) atraccións turísticas relixiosas, en forma de estruturas ou sitios de importancia relixiosa con interese histórico e/ou artístico; e (3) festivais con asociacións relixiosas. Segundo Vukonić (1996, p. 75), tamén hai tres formas principais de turismo relixioso: “(1) peregrinacións, (2) eventos relixiosos (reunións a grande escala con motivo de datas relixiosas importantes e aniversarios), e (3) un percorrido e unha visita a importantes lugares e edificios relixiosos no marco dun itinerario turístico".

Doutra banda, outros traballos céntranse en coñecer cales son as motivacións que levan a practicar este tipo de turismo, que a priori denominamos relixioso, pero que vén motivado por aspectos moi diversos e non sempre de carácter relixioso. 0 termo turismo relixioso, neste caso, está máis vinculado a que a fin do camiño está nun santuario de carácter relixioso, non no proceso que se vive durante a realización do camiño, o cal varía duns individuos a outros. Os estudosos do turismo descubriron que os turistas poden visitar lugares sacros por razóns como a apreciación da natureza e o enriquecemento educativo e cultural (Ron, 2009), incluída a relaxación e o autodescubrimento, non en todos os casos por unha crenza relixiosa. Chaspoul e Lunven (1993) agrupan todas as motivacións en catro perspectivas en función da demanda:

- A perspectiva espiritual. 0 turismo relixioso é un medio para que o individuo poida achegarse a Deus. Algúns turistas son crentes e a peregrinación e o retiro espiritual inclúense na súa parte práctica da fe. Outros turistas son atraídos por unha emoción, un lugar, un clima e o seu ambiente, que lle permiten un diálogo e unha consolidación da súa fe durante a súa viaxe ou visita ao lugar sacro.

-A perspectiva sociolóxica. 0 turismo relixioso é un medio para que o crente poida coñecer mellor a historia do grupo relixioso ao que pertence, e unir os seus vínculos coa comunidade. 
-A perspectiva cultural. A visita aos lugares de culto e santuarios é un medio para que o individuo, sexa crente ou non, poida entender as relixións presentes nas sociedades desde un punto de vista histórico, sociolóxico, simbólico, etnolóxico, cultural ou incluso desde un punto de vista político.

-A perspectiva xeográfica. Os directivos dos destinos de turismo relixioso observan as modificacións nos fluxos de turistas e tratan de ir adaptándose á evolución do mercado do turismo.

Porcal (2006) matiza que non todos os peregrinos son turistas, nin todos os turistas son peregrinos, frase que concreta moi ben a esencia actual do turismo relixioso en xeral, e do caso do Camiño de Santiago no traballo que nos ocupa. Na actualidade o turismo cultural está intimamente ligado ao relixioso, ao non ser a peregrinación estritamente relixiosa, senón que adquire novos matices como visitas ao patrimonio histórico-artístico ou etnográfico (Porcal, 2006) ou o gozo da paisaxe e da natureza xa mencionados. Wang, Luo e Tang (2015), dentro da teoría de factores push e pull das motivacións, conclúen no seu estudo que a crenza relixiosa ou a relaxación mental serían factores push para practicar turismo relixioso, e o gozo cultural sería un factor pull. Nicolaides (2016) fala no seu estudo de turistas relixiosos que buscan escapar do estrés da vida diaria e outros cuxa motivación é coñecer diversas visións do mundo e estilos de vida, ou experimentar con outras culturas. Olsen e Guleke (2004) explican ademais que algúns turistas viaxan para manter unha identidade, ou para satisfacer un sentimento de nostalxia, para experimentar o transcendente ou para cumprir as ensinanzas de certa relixión. Estes estudos non fan máis que reafirmar que a día de hoxe o turismo relixioso vai moito más aló da relixión, polo que xa non é para moitos a motivación principal para realizar algún tipo de peregrinación.

Á hora de falar de turismo relixioso, non podemos negar que o Camiño de Santiago é un referente mundial. A súa historia remóntase a principios do século IX. Paio, un ermitán, descubriu a tumba do apóstolo Santiago, un dos 12 apóstolos, condenado á morte por Herodes Agripa no ano 44 d.C. A tradición sitúa a Santiago como propagador do cristianismo na Península Ibérica entre os anos 33 e 43 d.C. Segundo a crónica medieval, a vitoria cristiá na batalla de Clavijo contra os mouros no ano 844, grazas á invocación a Santiago, converte a figura do apóstolo en símbolo da España reconquistada (Poutet, 2000). Foi o primeiro apóstolo declarado mártir. Desde Galilea o seu corpo foi trasladado cruzando o mar ata Santiago de Compostela, no noroeste da actual España (Cazaux, 2011). A partir diso, créanse unha serie de rutas que dan mostra da fe do peregrino. É tal o interese que suscita o Camiño na actualidade que isto se reflicte tamén no incremento de investigacións sobre este tema no século actual (Amaro, Antunes e Henriques, 2018; Gigirey, 2003; Gracia, 2005; Herrero, 2009; Lois González e López, 2015; Otero, 2009; Santos, 2006; Santos e Lois González, 2011; Somoza e Lois González, 2017).

Para o destino Galicia, o Camiño de Santiago é un produto referente a nivel internacional, tanto no seu modelo de xestión, na imaxe de marca como carta de presentación, no desenvolvemento socioeconómico, como particularmente no seu papel dinamizador nos concellos do rural (Martínez et al., 2018).

Realizar o Camiño de Santiago xorde como compromiso de fe, manifesto público de crenza na herdanza de Santiago e na conversión dos valores do orgullo e do egoísmo en amor (Fernández e Naranjo, 2010). Son varias as rutas que se crean para isto. Considéranse camiños históricos os que cumpren os seguintes requisitos (Fernández e Naranjo, 2010):

-Existencia dun trazado histórico definido, de uso continuo e dotado de vella cartografía.

- Nomes de aldeas relacionados co Camiño: Santiago, María Magdalena, Camiño, Oca, Ganso, Templarios, Real, Hospital...

-Rede histórica de hospitais (Misericordia) ao longo do Camiño, así como a existencia de pontes, calzadas, aldeas con arquitectura xacobea, outros monumentos e feitos.

- Documentos históricos e correspondencia de peregrinos que avalen o seu uso; milagres e lendas de peregrinos ao longo do Camiño; tradición oral que avale o paso de peregrinos.

-Igrexas e capelas con imaxes do apóstolo e arquitectura románica. 
Segundo Fernández e Naranjo (2010), o Camiño de Santiago é un camiño cunha meta, definindo cada peregrino o seu. Así existen ditos como "hai tantos camiños como peregrinos", "o Camiño a Santiago comeza na porta da casa" ou "mil camiños, un destino". Na Idade Media esta ruta de peregrinación foi moi concorrida, perdendo importancia tras o século XIV, dadas as convulsións sociais europeas, pero na época actual volveu obter un grande auxe. Os recoñecementos do Camiño van desde ser declarado Patrimonio da Humanidade pola UNESCO e Itinerario Cultural Europeo polo Consello de Europa, xa mencionado na introdución, ata, por exemplo, recibir o título honorífico de Rúa Maior de Europa (Andrade e Caamaño, 2016).

Aínda que os camiños poden ser variados, podemos dicir que son 12 os principais (Pilgrim, 2020). A Vía da Prata é o que presenta a lonxitude maior, con 960 quilómetros, seguido polo do Norte (824) e dun dos de maior renome mundial, o Francés (764). Inclúese tamén como un camiño máis o de Fisterra-Muxía, que supón unha continuación desde Santiago ata a costa ou ben pode facerse o camiño inverso en dirección a Santiago, coma o resto dos itinerarios (Táboa 1). Destes 12, algúns autores destacan oito camiños como os máis coñecidos: o Francés, o Portugués, o Portugués pola Costa, o do Norte, o Primitivo, o Inglés, o de Fisterra-Muxía e a Vía da Prata (Figura 1).

Táboa 1. Principais Camiños de Santiago

\begin{tabular}{llccc}
\hline Camiño & Inicio & Lonxitude $(\mathrm{km})$ & Etapas a pé & Etapas en bicicleta \\
\hline Francés & St. Jean Pied de Port (Francia) & 764 & 33 & 14 \\
Portugués & Lisboa & 620 & 24 & 11 \\
Do Norte & Irún & 824 & 34 & 18 \\
Primitivo & Oviedo & 313 & 14 & 7 \\
Inglés & Ferrol/A Coruña & 119 & 6 & - \\
Portugués pola Costa & O Porto & 304 & 13 & 4 \\
Epílogo Fisterra-Muxía & Santiago & 90 & 4 & - \\
De Inverno & Ponferrada & 263 & 10 & 7 \\
Sanabrés & Granja de la Moruela & 369 & 13 & 16 \\
Vía da Prata & Sevilla & 960 & 38 & 3 \\
Aragonés & Somport & 205 & 6 & 4 \\
Vasco do Interior & Irún & $252 / 199$ & $12 / 9$ & - \\
\hline
\end{tabular}

Fonte: Pilgrim (2020).

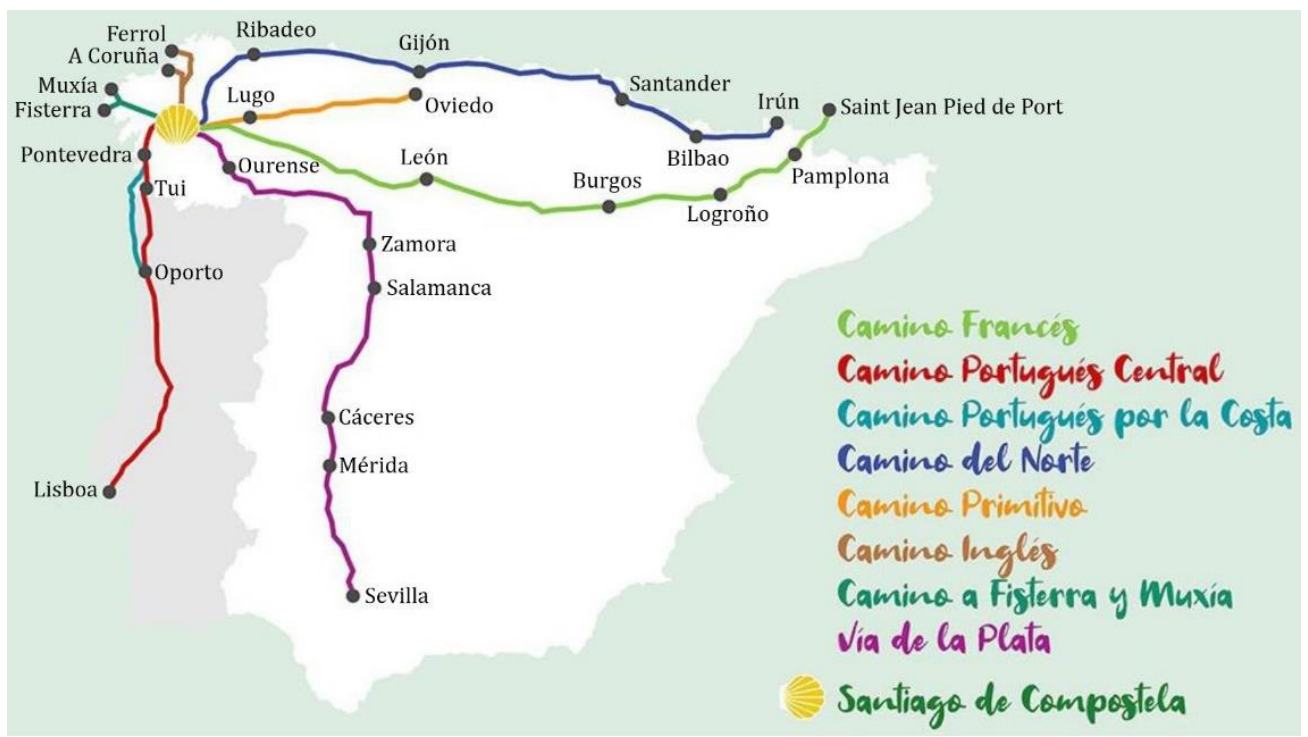

Figura 1. Principais Camiños de Santiago. Fonte: GalicianRoots (2020). 
No caso de Galicia, a peregrinación do Camiño de Santiago é moi importante, sendo a terceira motivación dos turistas que acoden a Galicia, comunidade autónoma na que se atopa Santiago de Compostela (Instituto Galego de Estatística [IGE], 2016). Así mesmo, esta rexión, consciente da proxección mundial do Camiño de Santiago, fixo uso deste como eixe central da súa campaña promocional. 0 Camiño de Santiago é o produto estrela da política turística galega (Fernández-Poyatos, Aguirregoitia Martínez e Boix Martínez, 2011). Na actualidade, aínda que se levou a cabo un maior fraccionamento da campaña promocional aludindo a diferentes produtos turísticos, o Camiño de Santiago segue a ter un peso importante, e así se reflicte no seu portal promocional (Turgalicia), onde son varias as imaxes e as palabras asociadas a este recurso (catedral, camiño, peregrino...). É tal a importancia do Camiño de Santiago neste destino que se oferta un propio menú na web para iso (Turgalicia, 2020).

\subsection{Camiño Nós}

Ademais dos diferentes camiños vistos na epígrafe anterior, na actualidade estase a traballar na posta en valor dunha ruta menos coñecida, unha variante da Vía da Prata. En xuño de 1926, os membros da Xeración Nós, Javier Pardo, Ramón Otero Pedrayo, Vicente Risco, Lois Feixó, Monxardín e Antón Sánchez realizaron unha peregrinación desde Ourense a Santiago de Compostela. Como partiron de Ourense, era de esperar que optasen pola Vía da Prata, pero decidiron seguir outro camiño medieval recollido na cartografía de Domingo Fontán: a Verea Vella ou Camiño dos Arrieiros (Federación Española de Asociaciones de Amigos del Camino de Santiago, 2020). 0 trazado da viaxe quedou reflectido con detalle no relato "No Camiño de San-Yago", de Javier Pardo, na revista A Nosa Terra. Este relato, publicado por entregas, describe cada etapa en distintas publicacións entre xullo de 1926 e abril de 1927.

No ano 2020, centenario da Xeración Nós, ás portas dun novo Xacobeo e próxima tamén a celebración dos cen anos da viaxe, xorde a oportunidade de rememorar este acontecemento. Por este motivo foi creada a Asociación Camiño Xeración Nós (Pinal, 2020) co obxectivo de conseguir a declaración de Camiño Cultural para esta ruta como variante do Camiño de Santiago-Vía da Prata. A asociación está formada polos concellos de Ourense, Amoeiro, Maside, O Carballiño, O Irixo, Lalín, Silleda, A Estrada, Vedra e Boqueixón, e conta co apoio da Deputación Provincial de Ourense, da Consellería de Cultura da Xunta de Galicia e das fundacións Otero Pedrayo, Vicente Risco, Antón Losada Diéguez, Castelao e Insua dos Poetas.

O Camiño está formado por un total de 112 quilómetros repartidos en catro etapas, e ten o seu inicio no centro da cidade de Ourense. As dúas primeiras etapas son as máis extensas, con 35 e 38 quilómetros cada unha, e as dúas últimas as máis curtas, de 19 e 20 quilómetros, respectivamente (Figura 2).

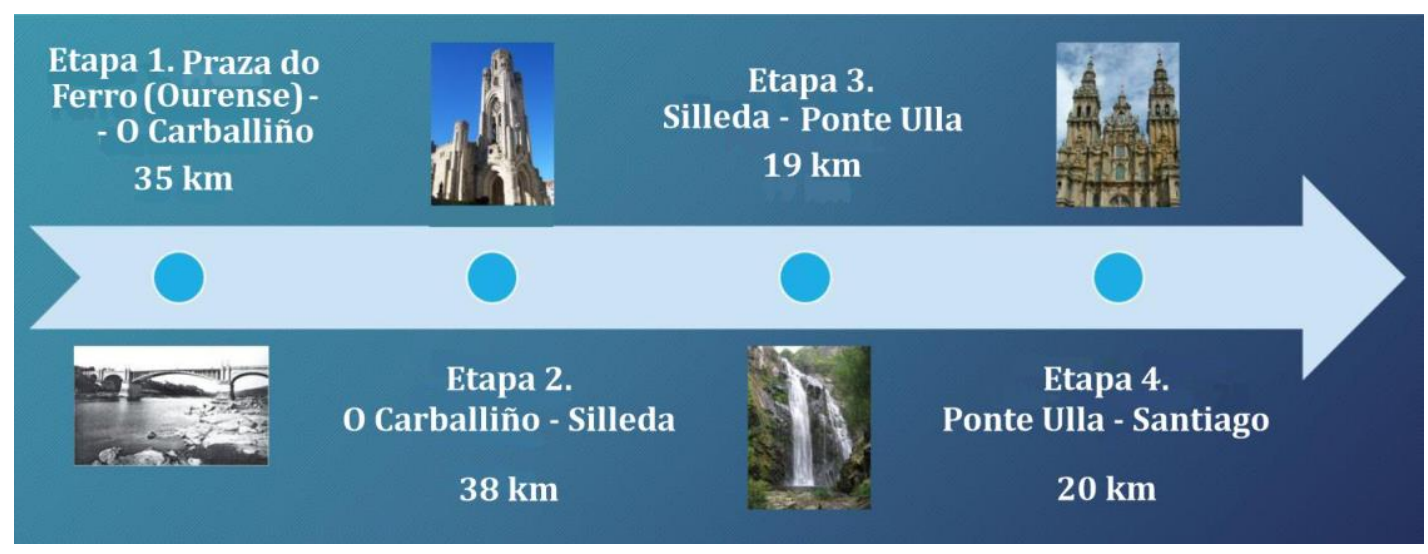

Figura 2. Etapas do Camiño Nós. Fonte: elaboración propia a partir de Pardo (1926-1927). 
A primeira etapa discorre pola provincia de Ourense. Parten da cidade das Burgas seguindo pola costiña de Canedo, Castro de Beiro, Beiro, Liñares, As Quintas e Rouzós ata Amoeiro, onde fan un descanso. Retoman o Camiño cara a Maside, pasando por Parada, San Fiz e Touza, finalizando esta primeira etapa no Carballiño sobre as 10 horas da noite (Figura 3). Ademais do Camiño, foron cubrindo un diario no que anotaron as experiencias vividas e incluso fotografías coa calidade existente naquel momento. Unha das anécdotas recollida no seu diario foi a parada da Garda Civil para pedirlles explicacións do que estaban a facer.

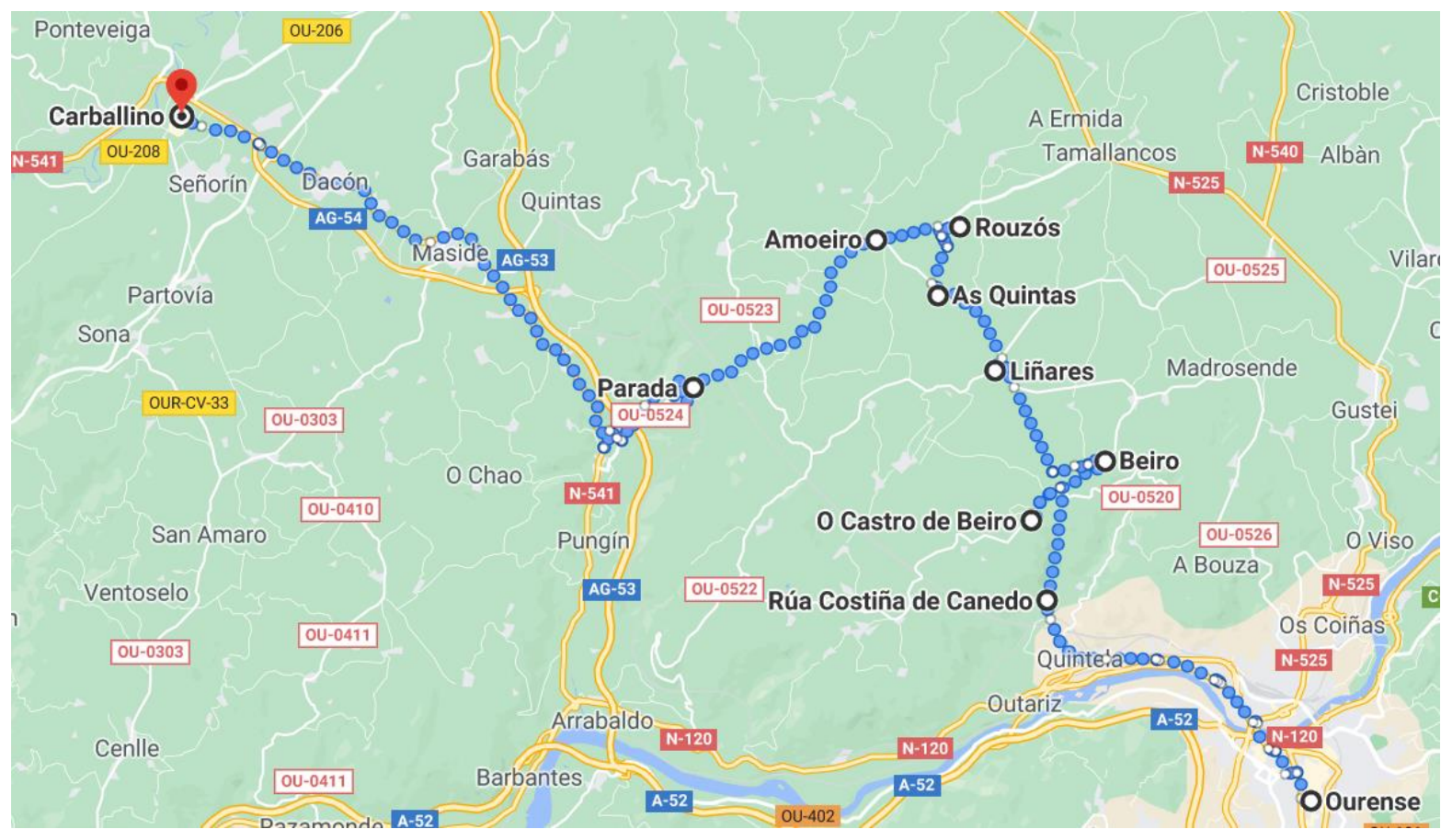

Figura 3. Primeira etapa do Camiño Nós. Ourense-O Carballiño. Fonte: elaboración propia a partir de Pardo (1926-1927).

O segundo día retoman o Camiño ás seis e media da mañá, con dirección a Silleda. No primeiro tramo pasan por Eirexa e Madarnás, facendo unha parada no Pazo de Madarnás. Continúan por Corneda, Couceiro, Dadín e paran a xantar no Irixo, á beira da ponte. 0 seguinte tramo é un dos máis difíciles, internándose na área montañosa da Dorsal Galega. Deixan ao seu paso Ermida do Fondo, Ermida do Medio, 0 Espino, Castiñeiras, Lebozán, Saborida, Lodeirón, Vilatuxe e Carballiñas, para chegar finalmente a Silleda, onde fan noite na casa de Trabazo (Figura 4).

Na terceira xornada toman rumbo cara a Ponte Ulla. Para iso trazan un camiño deixando ao seu paso a Chapa, Bandeira, San Pedro de Orazo e Balboa (Figura 5).

Por fin, a última parte deste Camiño, o Pico Sacro, onde os agardaban varios mozos do Seminario de Estudos Galegos, entre eles Lois Tobío, Martínez López, Requejo e Antonio Fraguas. Desde alí seguen cara a Compostela por Sergude, A Susana, O Castiñeiriño, A Pontepedriña, e ás dez da noite chegan ao centro de Santiago (Figura 6). Reclaman a Compostela ao día seguinte, cumprindo a norma de viaxar 100 quilómetros, desde a cidade das Burgas ata a cidade do Apóstolo. Reflíctese nos escritos da peregrinación do seguinte modo: "Como recordo perenne de este o noso paseo pola terra en busca de Santiago, todos gardamos a 'Compostela', un valioso diploma que cos anos terá a virtude de falar sempre dunha das etapas máis grotescas da nosa vida" (Federación Española de Asociaciones de Amigos del Camino de Santiago, 2020). 


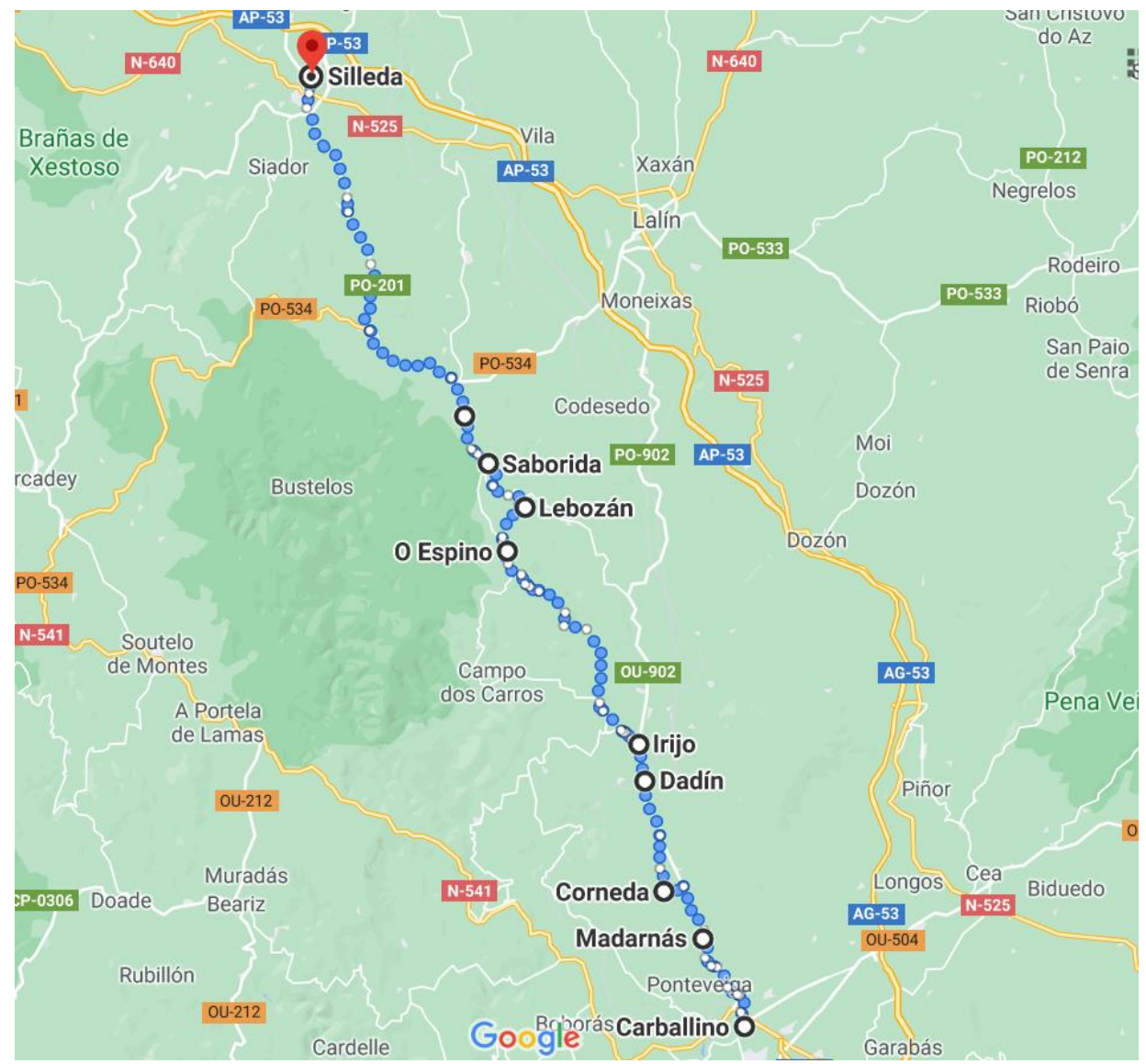

Figura 4. Segunda etapa do Camiño Nós. O Carballiño-Silleda. Fonte: elaboración propia a partir de Pardo (1926-1927).

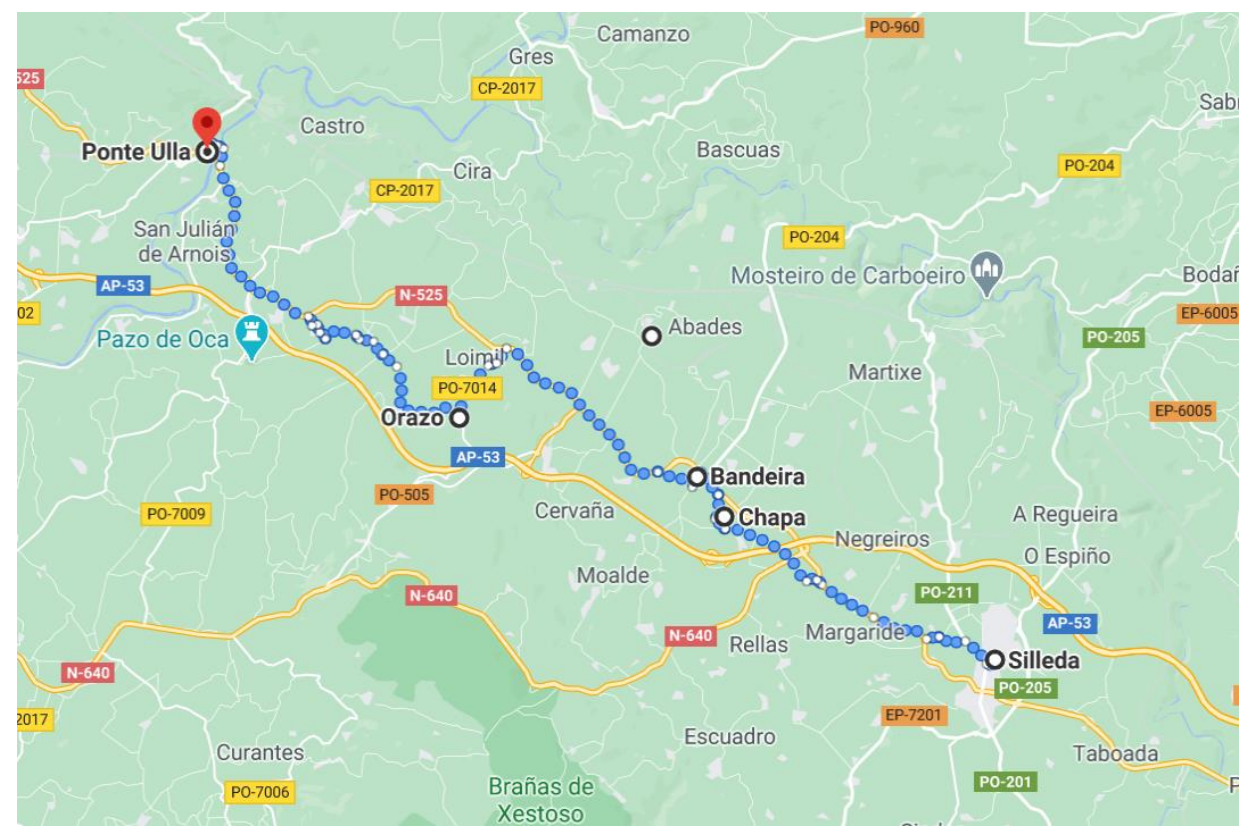

Figura 5. Terceira etapa do Camiño Nós. Silleda-Ponte Ulla. Fonte: eaboración propia a partir de Pardo (1926-1927). 


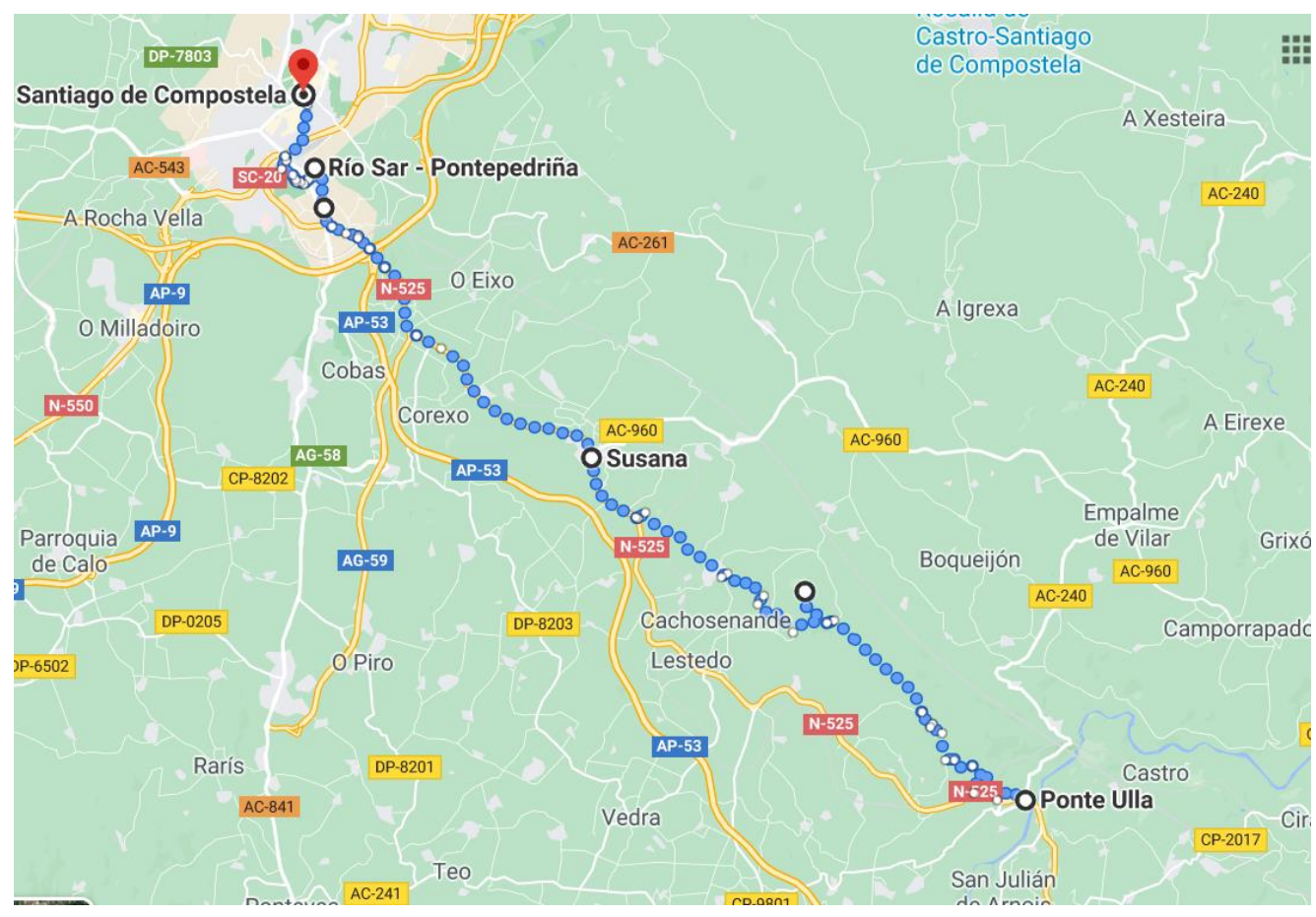

Figura 6. Cuarta etapa do Camiño Nós. Ponte Ulla-Santiago de Compostela. Fonte: elaboración propia a partir de Pardo (1926-1927).

\section{Materiais e métodos}

O obxectivo deste traballo é coñecer o consumo turístico durante a realización do Camiño xunto ás expectativas antes da súa execución, así como o coñecemento de novas rutas para chegar a Santiago. Como subobxectivos fíxanxe os seguintes:

-Verificar cales son os camiños máis transitados.

- Coñecer o grao de satisfacción coa experiencia do Camiño.

- Coñecer a intención de repetir o Camiño e de recomendalo.

-Estancia en Galicia unha vez finalizado o Camiño e os produtos turísticos consumidos.

- Coñecemento da Vía da Prata e da súa variante, o Camiño Nós.

-Interese no Camiño Nós.

Para alcanzar os obxectivos anteriores, optouse pola ferramenta de recollida de datos primarios da enquisa. Segundo Malhotra (2004), unha enquisa inclúe un cuestionario estruturado que se lles proporciona aos enquisados e que está deseñado para obter información específica. No caso do presente traballo, a enquisa e a súa estrutura foron deseñadas de tal forma que responda aos subobxectivos expostos anteriormente. En total, foron 26 as preguntas propostas, divididas en catro bloques, despois dunha primeira pregunta filtro sobre se o enquisado realizou ou non o Camiño de Santiago. As preguntas foron multirresposta, con escalas tipo Likert de 5 puntos e de resposta aberta.

-Bloque 1 (preguntas 2 a 13). Bloque destinado aos individuos que si realizaron o Camiño. Son 12 preguntas sobre o camiño realizado, satisfacción, intención de volta, intención de recomendación, estancia en Galicia, motivación e turismo consumido. Preguntas de resposta múltiple (camiño realizado, medio, tipo de aloxamento e hospedaxe) e de escala tipo Likert de 5 puntos (intención de volta, recomendación e turismos consumidos). Para as preguntas de turismos consumidos e tipos de alo- 
xamento pártese das preguntas deseñadas na Encuesta de turismo en destino de Galicia, que realiza a Área de Estudos e Investigación de Turismo de Galicia. Para establecer as motivacións, pártese dos traballos de Chaspoul e Lunven (1993), Porcal (2006), Ron (2009) e Wang et al. (2015), agrupándose finalmente todas as motivacións destes estudos en cinco grupos: relixiosa, espiritual, de lecer, deportiva e experiencial.

-Bloque 2 (preguntas 14 a 16). Bloque destinado aos individuos que non realizaron o Camiño. Intención de realizar o Camiño, que Camiño e consumo de turismo complementario. Neste caso son preguntas con escala tipo Likert do 1 ao 5 e preguntas multirresposta.

- Bloque 3 (preguntas 17 a 20). Coñecemento da Vía da Prata e do Camiño Nós e interese en obter máis información sobre o Camiño Nós tras explicar a súa historia. Preguntas dicotómicas (coñece a Vía da Prata e o Camiño Nós) e escala Likert de 1 a 5 puntos.

-Bloque 4 (preguntas 20 a 26). Perfil sociodemográfico. Preguntas dicotómicas, de única resposta e abertas (lugar de residencia) (ver enquisa completa no Anexo).

A poboación obxecto de estudo son os individuos particulares, polo que a técnica de mostraxe escollida foi a non probabilística de bóla de neve, é dicir, seleccionar un grupo inicial de enquisados e pedirlles que identifiquen a outros individuos que pertenzan á poboación obxecto de estudo aos que facer a enquisa, o que leva ao coñecido efecto bóla de neve (Malhotra, 2004). Mediante esta técnica recolléronse un total de 198 enquisas entre o 15 de decembro de 2020 e o 15 de xaneiro de 2021. Dada a situación de emerxencia sanitaria que se está a sufrir durante a realización deste estudo, a enquisa foi enviada vía mail e foi autoadministrada polo enquisado.

\section{Resultados}

\subsection{Perfil da mostra}

A mostra enquisada pertence na súa maioría ao territorio español, tendo certa presenza Bélxica $(3,0 \%)$, Francia $(2,0 \%)$ e A China $(1,5 \%)$. 0 xénero feminino é algo maioritario $(65,7 \%$ da mostra) e hai representatividade de todos os tramos de idade, principalmente entre os 16 e os 55 anos. O nivel educativo é moi alto, tendo o $86,4 \%$ estudos universitarios, e máis da metade están actualmente activos laboralmente, sendo na súa maioría traballadores/as por conta allea $(48,0 \%)$ (Táboa 2).

Táboa 2. Perfil da mostra

\begin{tabular}{lc}
\hline Xénero & $\%$ \\
\hline Mulleres & 65,7 \\
Homes & 34,3 \\
Idade & $\%$ \\
$16-25$ anos & 26,8 \\
$26-35$ anos & 21,7 \\
$36-45$ anos & 18,7 \\
$46-55$ anos & 24,2 \\
$56-65$ anos & 7,1 \\
Máis de 65 & 1,5 \\
Estudos & $\%$ \\
Estudos básicos & 8,1 \\
Estudos secundarios & 5,6 \\
Estudos universitarios & 86,4 \\
\hline
\end{tabular}


Táboa 2 (continuación). Perfil da mostra

\begin{tabular}{lc}
\hline Ocupación & $\%$ \\
\hline Traballador/a por conta allea & 48,0 \\
Traballador/a por conta propia & 8,6 \\
Desempregado/a & 15,2 \\
Estudante & 26,8 \\
Xubilado/a & 1,5 \\
País de residencia & $\%$ \\
España & 93,4 \\
Bélxica & 3,0 \\
Francia & 2,0 \\
China & 1,5 \\
Realizou algunha vez o Camiño de Santiago? & $\%$ \\
Si & 37,9 \\
Non & 62,1 \\
\hline
\end{tabular}

Fonte: elaboración propia.

Cómpre mencionar tamén neste epígrafe que, do total de enquisados, o 37,9\% realizaron algunha das rutas do Camiño de Santiago na súa vida. Do total da mostra recollida, 75 individuos fixeron o Camiño. Nesta submostra predomina lixeiramente o xénero feminino $(57,3 \%)$ pero en menor medida que no total; tamén predominan dous tramos de idade, o de 46 a 55 anos $(37,3 \%)$ e o de 26 a 35 anos $(24,0 \%)$; e os individuos teñen estudos superiores $(88,0 \%)$ e son todos españois (Táboa 3).

Táboa 3. Perfil da submostra dos que si realizaron o Camiño

\begin{tabular}{lc}
\hline Xénero & $\%$ \\
\hline Mulleres & 55,6 \\
Homes & 44,4 \\
Idade & $\%$ \\
$16-25$ anos & 15,7 \\
$26-35$ anos & 21,7 \\
$36-45$ anos & 9,6 \\
$46-55$ anos & 33,7 \\
$56-65$ anos & 6,0 \\
Máis de 65 & 13,3 \\
Estudos & $\%$ \\
Estudos básicos & 11,1 \\
Estudos secundarios & 7,2 \\
Estudos universitarios & 81,7 \\
Ocupación & $\%$ \\
Traballador/a por conta allea & 57,3 \\
Traballador/a por conta propia & 12,0 \\
Desempregado/a & 17,3 \\
Estudante & 9,3 \\
Xubilado/a & 4,0 \\
País de residencia & $\%$ \\
España & 100,0 \\
\hline
\end{tabular}

Fonte: elaboración propia. 
A submostra dos que aínda non realizaron o Camiño está composta por 123 individuos. No relativo ao xénero, a maior porcentaxe é feminina (70,7\%), e hai representación de todos os grupos de idade de modo bastante homoxéneo, agás de 56 anos en adiante que ten unha representación minoritaria, incluso 0 a partir de 65 anos. 0 85,4\% posúe estudos superiores, o 13,0\% básicos e tan só o 1,6\% secundarios. No que respecta á ocupación, son dous os grupos predominantes: traballadores/as por conta allea $(43,9 \%)$ e estudantes $(37,4 \%)$ (Táboa 4$)$.

Táboa 4. Perfil da submostra dos que non realizaron o Camiño

\begin{tabular}{lc}
\hline Xénero & $\%$ \\
\hline Mulleres & 70,7 \\
Homes & 29,3 \\
Idade & $\%$ \\
$16-25$ anos & 31,2 \\
$26-35$ anos & 21,3 \\
$36-45$ anos & 23,8 \\
$46-55$ anos & 16,3 \\
$56-65$ anos & 7,4 \\
Máis de 65 & 0,0 \\
Estudos & $\%$ \\
Estudos básicos & 13,0 \\
Estudos secundarios & 1,6 \\
Estudos universitarios & 85,4 \\
Ocupación & $\%$ \\
Traballador/a por conta allea & 43,9 \\
Traballador/a por conta propia & 4,1 \\
Desempregado/a & 14,6 \\
Estudante & 37,4 \\
Xubilado/a & 0,0 \\
País de residencia & $\%$ \\
España & 89,4 \\
Bélxica & 4,9 \\
Francia & 3,3 \\
China & 2,4 \\
\hline
\end{tabular}

Fonte: elaboración propia.

Por último, aparece unha terceira submostra cos individuos que coñecen o Camiño Nós, tan só o $10,1 \%$ dos enquisados. Neste caso, o xénero está igualado (50\%-50\%) e todos os individuos son menores de 46 anos, destacando os individuos de 26 a 35 anos (50\% desta submostra). Tamén hai que destacar que o $95 \%$ son españois e o $5 \%$ de procedencia chinesa.

\subsection{Análise de individuos que fixeron o Camiño}

No tocante aos camiños realizados, son cinco os elixidos, por orde de preferencia: o Camiño Francés, o Camiño Inglés, o Camiño Portugués, a Vía da Prata e o Camiño do Norte. Ademais, aínda que o valor maioritario é ter feito unha vez o Camiño (64,0\% da mostra), o 33,4\% repetiu a experiencia entre dúas e tres veces (Figura 7).

Atópanse diferenzas significativas na variable xénero, sendo o xénero masculino o que realizou máis veces o Camiño e sendo o habitual nas mulleres unha soa vez. Aínda que como valores atípicos, 
pódese mencionar os dous individuos que realizaron o Camiño catro veces, ambas mulleres. Verbo da variable idade, tamén observamos certas diferenzas. Só nos grupos de idade de 16 a 25 anos e de 36 a 55 anos os individuos chegaron a facer dúas veces o Camiño, sendo o grupo de 46 a 55 anos o que chegou incluso a tres veces. Os dous valores atípicos que realizaron o camiño catro veces, ademais de ser mulleres, están no tramo de 16 a 25 anos (Figuras 8 e 9). Por outra banda, máis da metade $(56,0 \%)$ realizou o Camiño hai máis de cinco anos. Non obstante, o 17,3\% realizouno no último ano e, en concreto, o $10,7 \%$ nos últimos seis meses, valores moi positivos ante a actual situación de pandemia mundial que se está a vivir. No que respecta ao modo de realizar o Camiño, hai unha tendencia clara: andando (90,0\% da mostra). 0 10,0\% restante correspóndese con individuos que realizaron máis dunha vez o Camiño, algunha delas andando e outra en bicicleta.

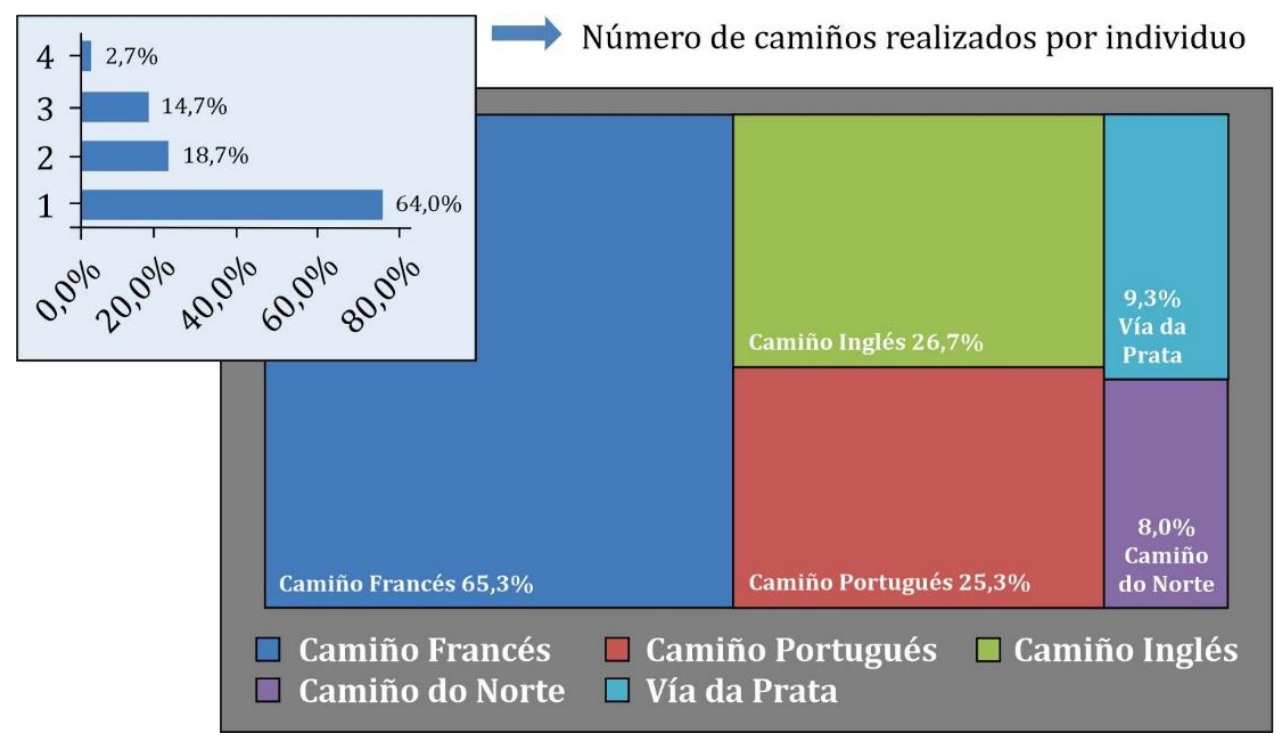

Figura 7. Camiños de Santiago máis transitados e número de camiños realizados por individuo (nos últimos 5 anos). Fonte: elaboración propia..

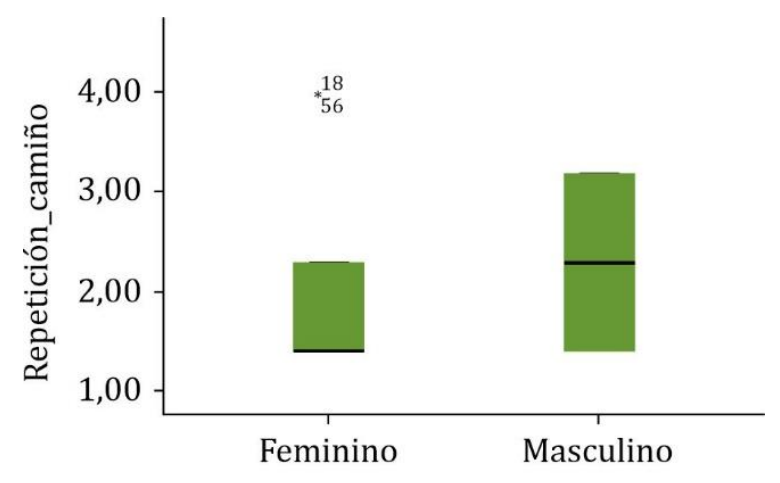

Xénero

Figura 8. Frecuencia de realización do Camiño nos últimos cinco anos en función da variable xénero. Fonte: elaboración propia..

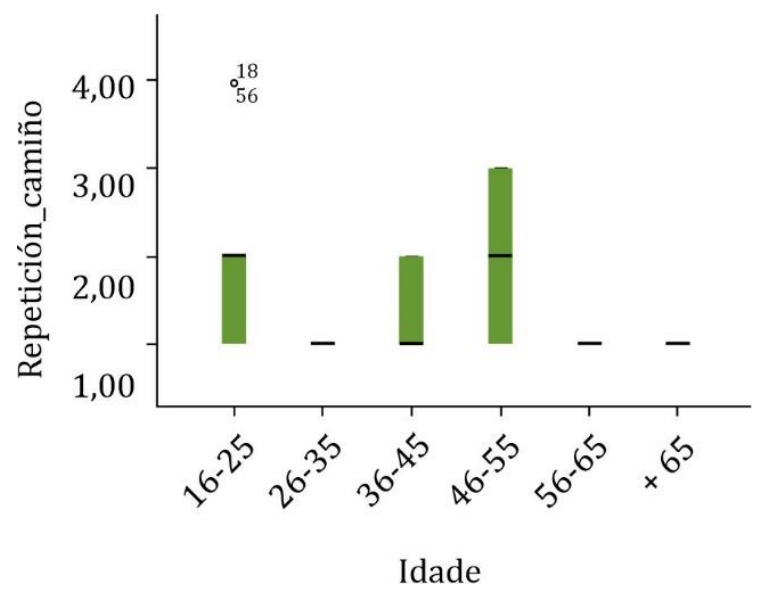

Figura 9. Frecuencia de realización do Camiño nos últimos cinco anos en función da variable idade. Fonte: elaboración propia.. 
No tocante ao grao de satisfacción, intención de volta e recomendación, tal e como se observa na Táboa 5, os valores obtidos son moi positivos, superiores a 4 (nunha escala do 1 ao 5) no caso da satisfacción e da intención de recomendación. 0 valor máis baixo correspóndese coa intención de repetir o Camiño, estando aínda así próximo ao 4. Ademais, no caso do grao de satisfacción o valor mínimo obtido en toda a submostra foi de 4 e o valor máis repetido o 5 . Se facemos unha análise en función das variables xénero e idade, no que respecta ao grao de satisfacción a valoración é similar, independentemente do xénero e da idade. No caso da intención de volta, as valoracións son lixeiramente superiores nos homes que nas mulleres, e no grupo de idade de 36 a 45 anos. Por último, a recomendación é algo maior por parte dos homes e nos grupos de idade de 16 a 25 anos, de 36 a 45 anos e de 56 a 65 anos, todos eles cun valor de 5, a valoración máis alta (Táboas 6 e 7).

Táboa 5. Grao de satisfacción, intención de volta e de recomendación do Camiño (escala Likert do 1 ao 5)

\begin{tabular}{lcccccc}
\hline & N & Mínimo & Máximo & Media & Moda & Desv. típ. \\
\hline Satisfacción & 75 & 4 & 5 & 4,81 & 5 &, 392 \\
Intención_volta & 75 & 2 & 5 & 3,88 & 3 &, 929 \\
Recomendación & 75 & 3 & 5 & 4,76 & 5 &, 589 \\
N válido & 75 & & & & & \\
\hline
\end{tabular}

Fonte: elaboración propia..

Táboa 6. Grao de satisfacción, intención de volta e de recomendación do Camiño (escala Likert do 1 ao 5) en función do xénero

\begin{tabular}{lccc}
\hline Xénero & Intención_volta & Satisfacción & Recomendación \\
\hline Feminino & 3,70 & 4,88 & 4,65 \\
Masculino & 4,13 & 4,72 & 4,91 \\
\hline
\end{tabular}

Fonte: elaboración propia..

Táboa 7. Grao de satisfacción, intención de volta e de recomendación do Camiño (escala Likert do 1 ao 5) en función da idade

\begin{tabular}{lccc}
\hline Idade & Intención_volta & Satisfacción & Recomendación \\
\hline $16-25$ anos & 3,31 & 5,00 & 5,00 \\
$26-35$ anos & 4,11 & 4,83 & 4,83 \\
$36-45$ anos & 4,75 & 4,75 & 5,00 \\
$46-55$ anos & 3,89 & 4,79 & 4,57 \\
$56-65$ anos & 3,00 & 5,00 & 5,00 \\
Máis de 65 anos & 4,00 & 4,00 & 4,00 \\
\hline
\end{tabular}

Fonte: elaboración propia..

No que respecta á duración da estancia en Galicia como parte da experiencia do Camiño, o valor máis repetido é entre catro e sete días (52\% da mostra), seguido de entre dous e catro días (16\%), de máis de dez días $(14,7 \%)$ e finalmente de entre sete e dez días, a estancia menos habitual $(5,3 \%)$. Ademais, o 72\% decide alongar a súa permanencia en Galicia unha vez finalizado o Camiño, sendo o valor maioritario desta estadía extra de dous días máis. 
A continuación analízanse os tipos de turismo consumidos durante a experiencia do Camiño (Táboa 8). Para iso proponse un constructo conformado por once ítems. Na Táboa 8 obsérvase que os máis consumidos son o turismo gastronómico $(3,31)$, a visita a puntos de interese turístico $(2,99)$ e a visita a museos e monumentos $(2,83)$.

No relativo ao aloxamento, o principal son os albergues $(76,0 \%)$, seguido moi de lonxe polas casas de amigos e familiares (14,7\%) (Figura 10).

Táboa 8. Tipos de turismo consumidos durante a experiencia do Camiño. Escala Likert de 1 a 5 puntos

\begin{tabular}{llllll}
\hline & N & Mínimo & Máximo & Media & Desv. típ. \\
\hline Compras & 75 & 1,00 & 5,00 & 1,73 &, 93481 \\
Praia_costa & 75 & 1,00 & 5,00 & 1,91 & 1,39665 \\
Enoturismo & 75 & 1,00 & 4,00 & 1,72 & 1,14561 \\
Relaxación & 75 & 1,00 & 4,00 & 1,72 & 1,07251 \\
Interese_turístico & 75 & 1,00 & 5,00 & 2,99 & 1,56389 \\
Museos_monumentos & 75 & 1,00 & 5,00 & 2,83 & 1,45540 \\
Parques_naturais & 75 & 1,00 & 5,00 & 2,12 & 1,33518 \\
Lecer_nocturno & 75 & 1,00 & 5,00 & 2,23 & 1,59029 \\
Excursións & 75 & 1,00 & 5,00 & 2,47 & 1,57971 \\
Termalismo & 75 & 1,00 & 4,00 & 1,61 & 1,06407 \\
Gastronomía & 75 & 1,00 & 5,00 & 3,31 & 1,54197 \\
N válido (segundo lista) & 75 & & & & \\
\hline
\end{tabular}

Fonte: elaboración propia..

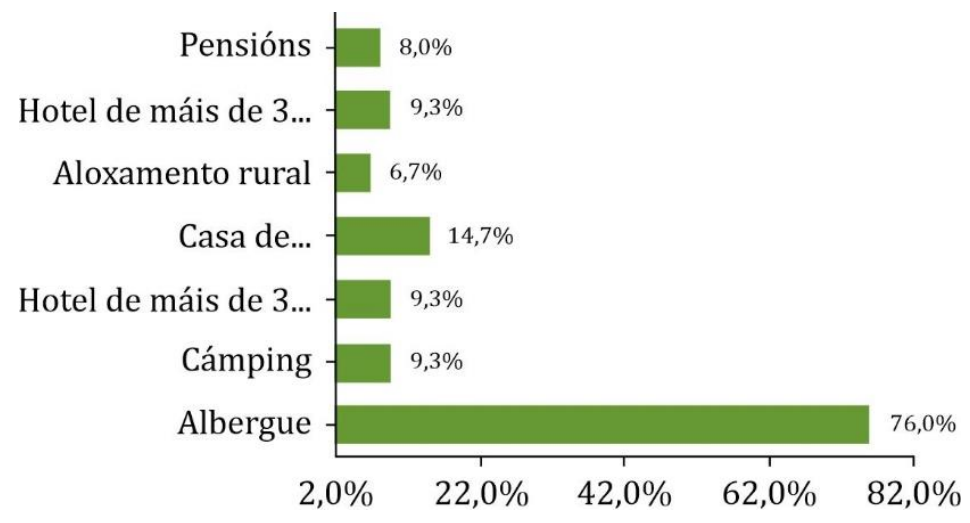

Figura 10. Tipo de aloxamento. Fonte: elaboración propia..

Co fin de verificar se o consumo turístico é homoxéneo, analízase esta variable en función das variables sociodemográficas (xénero, idade e ocupación), para o que se aplica o estatístico non paramétrico test chi-cadrado de Pearson. Todas as variables mostran unha significación inferior a 0,05, agás a ocupación e a relaxación, polo que en todas hai diferenzas significativas salvo a mencionada excepción. No caso do xénero, o feminino dá puntuacións máis altas a gozar de praia e costa, mentres que o masculino o fai ao resto de tipos de turismo. No relativo á idade, o grupo máis novo -de 16 a 25 años- valora máis o dozo da praia e costa, a visita de puntos de interese turístico, a visita a museos e monumentos, o lecer nocturno, as excursións e a gastronomía. As compras e as visitas a parques naturais son de maior interese para o grupo de 46 a 55 anos, e o enoturismo, o termalismo e tamén a relaxación para 
os de 56 a 65 anos. No tocante á ocupación, os estudantes mostran maior interese no gozo de praia e costa, nas excursións e no lecer nocturno.

No que respecta á motivación que leva a facer o Camiño, son dúas as principais: o lecer $(42,7 \%)$ e a experiencial (38,7\%) (Figura 11). E os aspectos máis valorados do Camiño pódense agrupar en: a experiencia en si, a tranquilidade, as amizades e os peregrinos que se coñecen no Camiño, a natureza e a paisaxe, a desconexión e a soidade.

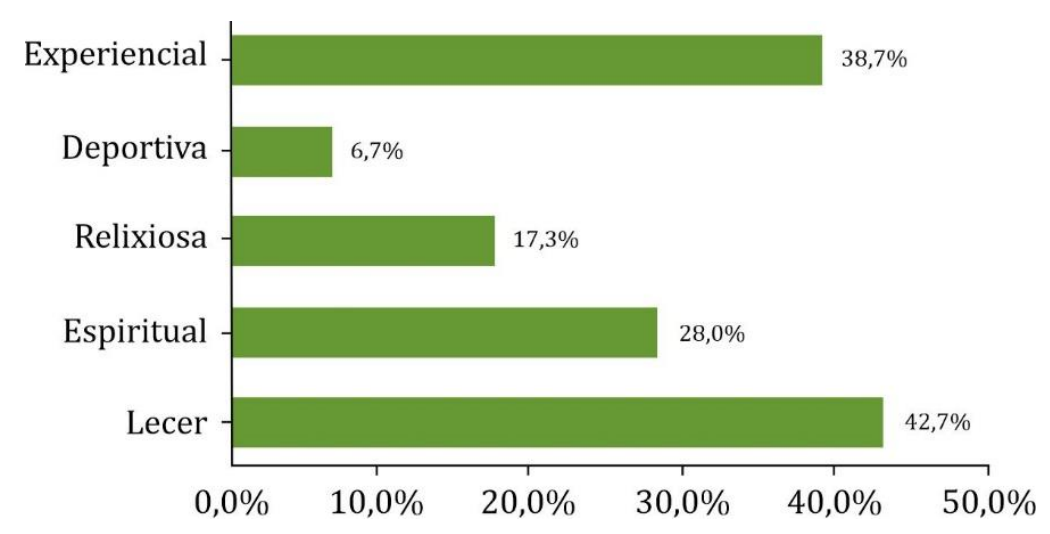

Figura 11. Motivación para realizar o Camiño. Fonte: elaboración propia..

\subsection{Análise de individuos que non fixeron o Camiño}

Nunha escala do 1 ao 5 que mide a intención de realizar o Camiño, o valor medio obtido é de 3,68. Aplícase o estatístico non paramétrico test chi-cadrado de Pearson para verificar se a intención é homoxénea en toda a submostra en función das variables sociodemográficas. Son dúas as variables nas que se atopan maiores diferenzas: a idade, presentando maior intención os grupos de 26 a 35 anos e de 56 a 65 anos; e a ocupación, mostrando neste caso unha maior intención os traballadores por conta propia (Figuras 12 e 13).

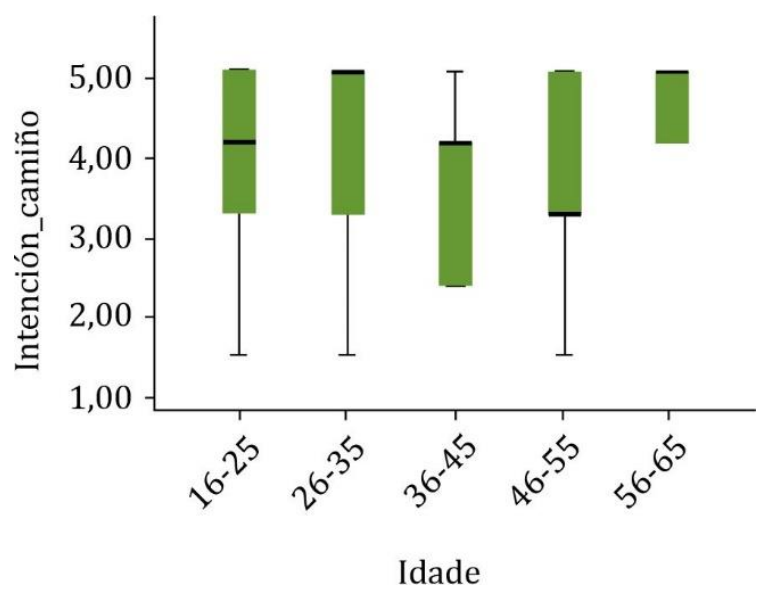

Figura 12. Intención de realizar o Camiño en función da idade. Fonte: elaboración propia..

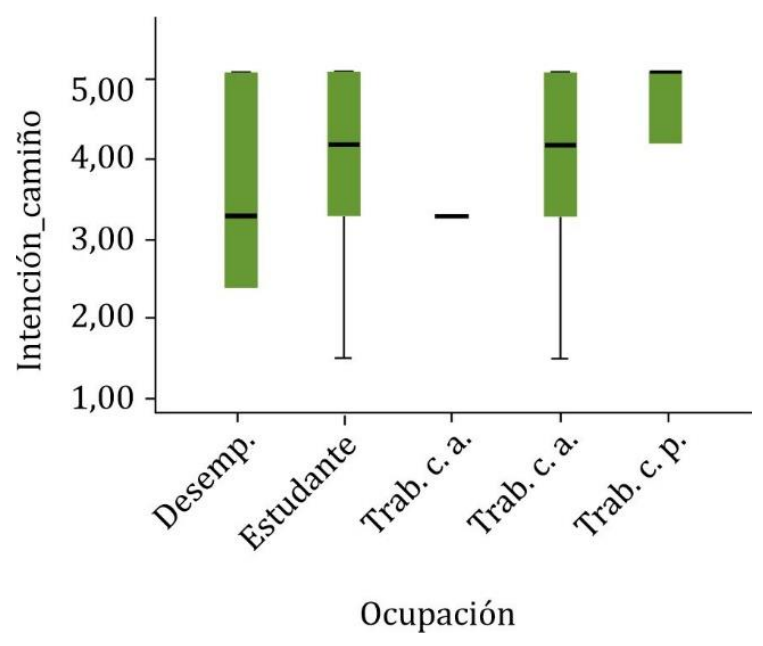

Figura 13. Intención de realizar o Camiño en función da ocupación. Nota: Desemp.: desempregado/a, Trab. c.a.: traballador/a por conta allea, Trab. c.p.: traballador/a por conta propia. Fonte: elaboración propia.. 
Ao igual que aos individuos que realizaron o Camiño se lles pregunta polos tipos de turismo consumidos durante a experiencia, neste caso búscase coñecer a expectativa de consumo dos que aínda non fixeron o Camiño. Neste caso, de novo a gastronomía presenta o valor máis alto $(4,07)$, seguido da visita a museos e monumentos $(3,60)$ e da visita a puntos de interese turístico $(3,54)$. Coinciden bastante as expectativas co consumo dos que xa fixeron o Camiño, estando neste caso a visita a museos e monumentos en segundo lugar e nos que xa fixeron o Camiño no terceiro (Táboa 9).

Aplícase de novo o estatístico non paramétrico test chi-cadrado de Pearson para verificar se hai diferenzas significativas nesta submostra entre o xénero, a idade e a ocupación. Atópanse diferenzas entre o xénero e a relaxación (maior preferencia no xénero feminino), entre o xénero e o lecer nocturno (maior preferencia no xénero masculino), entre o xénero e a gastronomía (maior preferencia no xénero feminino), entre a idade e as compras (maior preferencia de 16 a 35 anos), entre a idade e o gozo de praia e costa (maior preferencia nos máis novos, de 16 a 25 anos), entre a idade e o enoturismo (maior preferencia no grupo de 26 a 45 anos), entre a idade e a visita a parques naturais (maior preferencia no grupo de 16 a 35 anos), entre a idade e o lecer nocturno (maior preferencia nos máis novos, de 16 a 35 anos), entre a idade e as excursións (maior preferencia nos de 26 a 35) e entre a idade e o termalismo (de 36 a 45 anos). No caso da ocupación, os estudantes mostran maior preferencia polas compras, polo gozo de praia e costa, pola visita a puntos de interese turístico, pola visita a museos e monumentos, pola visita a parques naturais, polas excursións e polo lecer nocturno. Os traballadores por conta allea mostran maior preferencia pola gastronomía e a relaxación.

No relativo ao Camiño que pensa realizar, a maioría da mostra inclínase polo Camiño Francés como alternativa, seguido polo Camiño do Norte e polo Camiño Portugués (Figura 14).

Táboa 9. Expectativa de consumo durante a experiencia do Camiño. Escala Likert de 1 a 5 puntos

\begin{tabular}{lccccc}
\hline & N & Mínimo & Máximo & Media & Desv. típ. \\
\hline Compras & 123 & 0 & 5 & 1,59 & 1,207 \\
Praia_costa & 123 & 0 & 5 & 2,88 & 1,768 \\
Enoturismo & 123 & 1 & 5 & 3,13 & 1,493 \\
Relaxación & 123 & 0 & 5 & 2,91 & 1,765 \\
Interese_turístico & 123 & 0 & 5 & 3,54 & 1,661 \\
Museos_monumentos & 123 & 1 & 5 & 3,60 & 1,326 \\
Parques_naturais & 123 & 1 & 5 & 3,74 & 1,308 \\
Lecer_nocturno & 123 & 1 & 5 & 2,80 & 1,464 \\
Excursións & 123 & 1 & 5 & 2,96 & 1,370 \\
Termalismo & 123 & 1 & 5 & 3,30 & 1,209 \\
Gastronomía & 123 & 1 & 5 & 4,07 & 1,141 \\
N válido (segundo lista) & 123 & & & & \\
\hline
\end{tabular}

Fonte: elaboración propia..

\subsection{Comparativa entre os que fixeron o Camiño e os que non}

Tras analizar os comportamentos das submostras "os que fixeron o Camiño" e "os que aínda non fixeron o Camiño", crese interesante comparar certos aspectos entrambos. Na enquisa deseñouse unha pregunta común para ambos os colectivos: o turismo consumido durante o Camiño, para o primeiro caso, e o turismo que cren que consumirán cando fagan o Camiño, para o segundo, co fin de poder comparar a realidade coas expectativas. Tras aplicar unha análise ANOVA, sendo o factor común a realización do Camiño (si ou non), obsérvanse diferenzas significativas nas variables consumo de turismo de praia ou costa, enoturismo, relaxación, visita a parques naturais e termalismo (Táboa 10). 


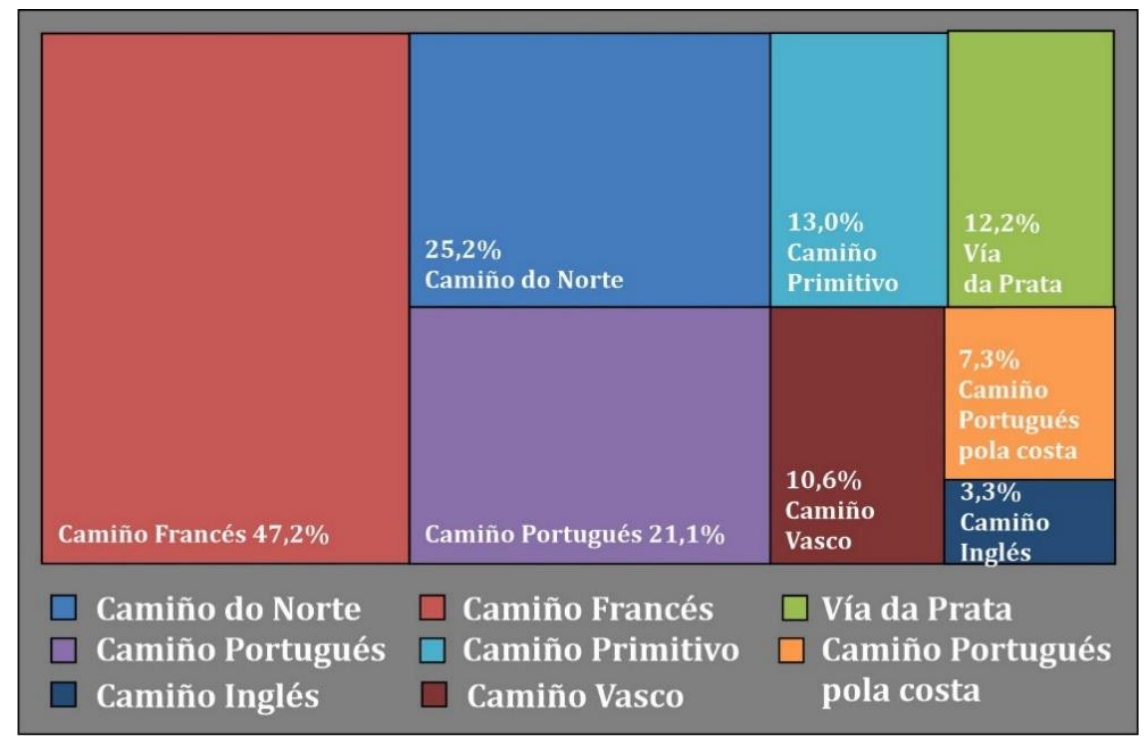

Figura 14. Camiño con intención de realizar. Fonte: elaboración propia..

Táboa 10. ANOVA de consumo e expectativas de consumo en función de ter realizado ou non o Camiño

\begin{tabular}{|c|c|c|c|c|c|c|}
\hline & & Suma de cadrados & gl & Media cuadrática & $\mathrm{F}$ & Sig. \\
\hline COMPRAS & $\begin{array}{l}\text { Inter-grupos } \\
\text { Intra-grupos } \\
\text { Total }\end{array}$ & $\begin{array}{c}6,333 \\
326,541 \\
332,874\end{array}$ & $\begin{array}{c}1 \\
196 \\
197\end{array}$ & $\begin{array}{l}6,333 \\
1,666\end{array}$ & 3,801 & ,053 \\
\hline PRAIA_COSTA & $\begin{array}{l}\text { Inter-grupos } \\
\text { Intra-grupos } \\
\text { Total }\end{array}$ & $\begin{array}{c}32,009 \\
530,764 \\
562,773\end{array}$ & $\begin{array}{c}1 \\
196 \\
197\end{array}$ & $\begin{array}{c}32,009 \\
2,708\end{array}$ & 11,820 & 001 \\
\hline ENOTURISMO & $\begin{array}{l}\text { Inter-grupos } \\
\text { Intra-grupos } \\
\text { Total }\end{array}$ & $\begin{array}{c}34,194 \\
454,619 \\
488,813\end{array}$ & $\begin{array}{c}1 \\
196 \\
197\end{array}$ & $\begin{array}{c}34,194 \\
2,319\end{array}$ & 14,742 & ,000 \\
\hline RELAXACIÓN & $\begin{array}{l}\text { Inter-grupos } \\
\text { Intra-grupos } \\
\text { Total }\end{array}$ & $\begin{array}{c}64,699 \\
482,619 \\
547,318\end{array}$ & $\begin{array}{c}1 \\
196 \\
197\end{array}$ & $\begin{array}{c}64,699 \\
2,462\end{array}$ & 26,276 & ,000 \\
\hline INT_TURÍSTICO & $\begin{array}{l}\text { Inter-grupos } \\
\text { Intra-grupos } \\
\text { Total }\end{array}$ & $\begin{array}{c}12,086 \\
519,914 \\
532,000\end{array}$ & $\begin{array}{c}1 \\
196 \\
197\end{array}$ & $\begin{array}{c}12,086 \\
2,653\end{array}$ & 4,556 & 034 \\
\hline MUSEOS & $\begin{array}{l}\text { Inter-grupos } \\
\text { Intra-grupos } \\
\text { Total }\end{array}$ & $\begin{array}{c}1,655 \\
526,163 \\
527,818\end{array}$ & $\begin{array}{c}1 \\
196 \\
197\end{array}$ & $\begin{array}{l}1,655 \\
2,685\end{array}$ & 616 & ,433 \\
\hline P_NATURALES & $\begin{array}{l}\text { Inter-grupos } \\
\text { Intra-grupos } \\
\text { Total }\end{array}$ & $\begin{array}{c}79,337 \\
475,253 \\
554,591\end{array}$ & $\begin{array}{c}1 \\
196 \\
197\end{array}$ & $\begin{array}{c}79,337 \\
2,425\end{array}$ & 32,720 & ,000 \\
\hline LECER_NOC & $\begin{array}{l}\text { Inter-grupos } \\
\text { Intra-grupos } \\
\text { Total }\end{array}$ & $\begin{array}{c}10,984 \\
387,744 \\
398,728\end{array}$ & $\begin{array}{c}1 \\
178 \\
179\end{array}$ & $\begin{array}{c}10,984 \\
2,178\end{array}$ & 5,042 & ,026 \\
\hline EXCURSIÓN & $\begin{array}{l}\text { Inter-grupos } \\
\text { Intra-grupos } \\
\text { Total }\end{array}$ & $\begin{array}{c}10,613 \\
394,448 \\
405,061\end{array}$ & $\begin{array}{c}1 \\
177 \\
178\end{array}$ & $\begin{array}{c}10,613 \\
2,229\end{array}$ & 4,762 & 030 \\
\hline TERMALISMO & $\begin{array}{l}\text { Inter-grupos } \\
\text { Intra-grupos } \\
\text { Total }\end{array}$ & $\begin{array}{l}122,793 \\
241,366 \\
364,159 \\
\end{array}$ & $\begin{array}{c}1 \\
174 \\
175 \\
\end{array}$ & $\begin{array}{c}122,793 \\
1,387\end{array}$ & 88,521 & ,000 \\
\hline
\end{tabular}

Fonte: elaboración propia.. 
En todos os casos nos que hai diferenzas significativas, as expectativas de consumir ese tipo de turismo son máis altas que o consumo real durante o Camiño (Figuras 15 a 19).

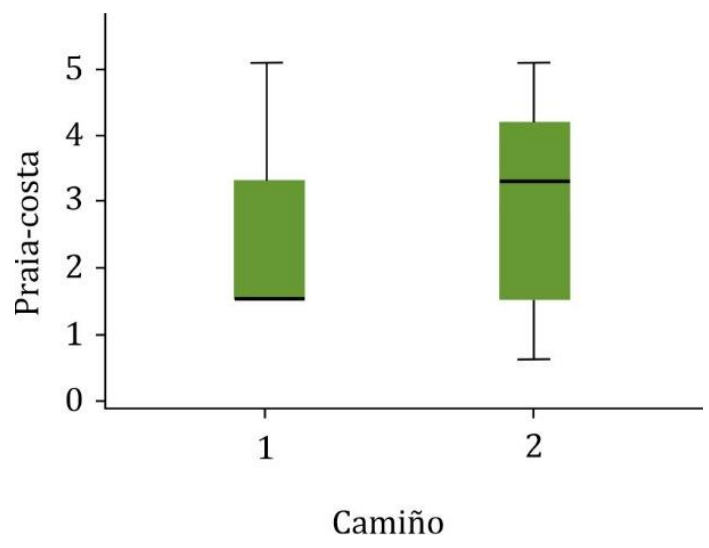

Figura 15. Comparativa de consumo turístico en función de ter realizado xa o Camiño (grupo 1) e non o ter realizado aínda (grupo 2). Praia-costa. Fonte: elaboración propia..

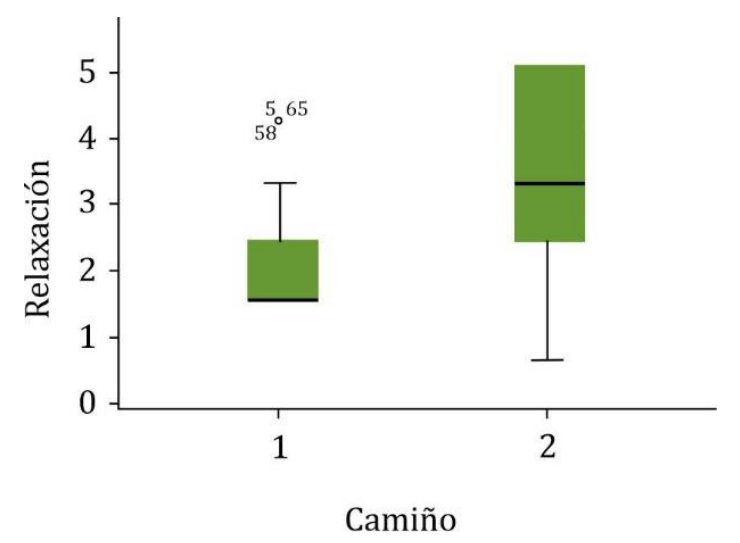

Figura 17. Comparativa de consumo turístico en función de ter realizado xa o Camiño (grupo 1) e non o ter realizado aínda (grupo 2). Relaxación. Fonte: elaboración propia..

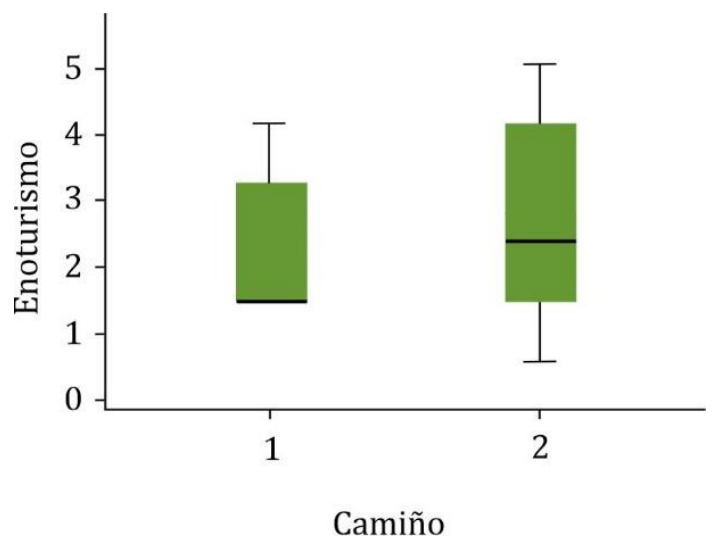

Figura 16. Comparativa de consumo turístico en función de ter realizado xa o Camiño (grupo 1) e non o ter realizado aínda (grupo 2). Enoturismo. Fonte: elaboración propia..

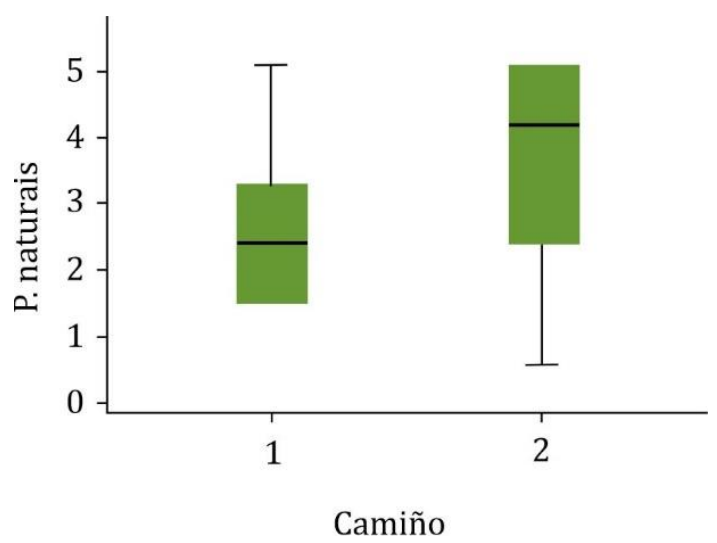

Figura 18. Comparativa de consumo turístico en función de ter realizado xa o Camiño (grupo 1) e non o ter realizado aínda (grupo 2). Parques naturais. Fonte: elaboración propia..

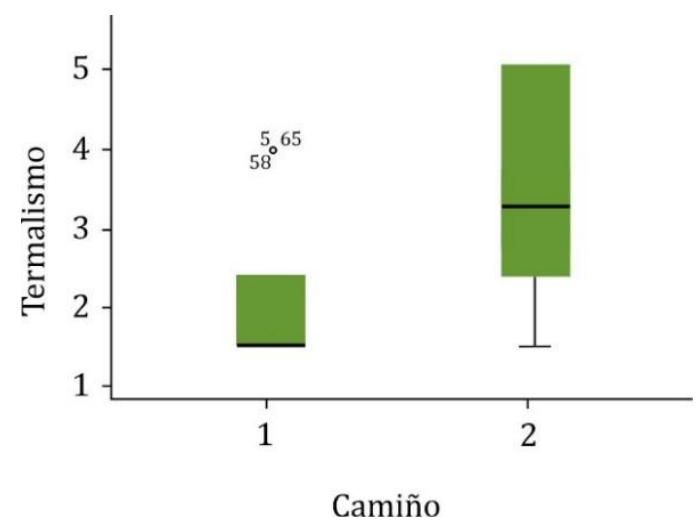

Figura 19. Comparativa de consumo turístico en función de ter realizado xa o Camiño (grupo 1) e non o ter realizado aínda (grupo 2). Termalismo. Fonte: elaboración propia.. 
Realízase unha análise co estatístico chi-cadrado para verificar se hai diferenzas no consumo ou expectativas de consumo en función da variable xénero, e obtéñense diferenzas significativas no caso do enoturismo, máis alto no xénero masculino; na visita aos museos, máis alto no xénero masculino; e no lecer nocturno, máis alto tamén no xénero masculino. No resto de produtos non se atopan diferenzas altamente significativas.

\subsection{Coñecemento do Camiño Nós}

Analízase para esta epígrafe o total da mostra, comprobando o coñecemento dos individuos da Vía da Prata $(74,2 \%$ da mostra) e do Camiño Nós, moito menos coñecido $(10,1 \%)$. Existe unha alta correlación entre as dúas variables, ao seren coñecedores o 85\% dos que coñecen o Camiño Nós tamén da Vía da Prata (Figura 20).

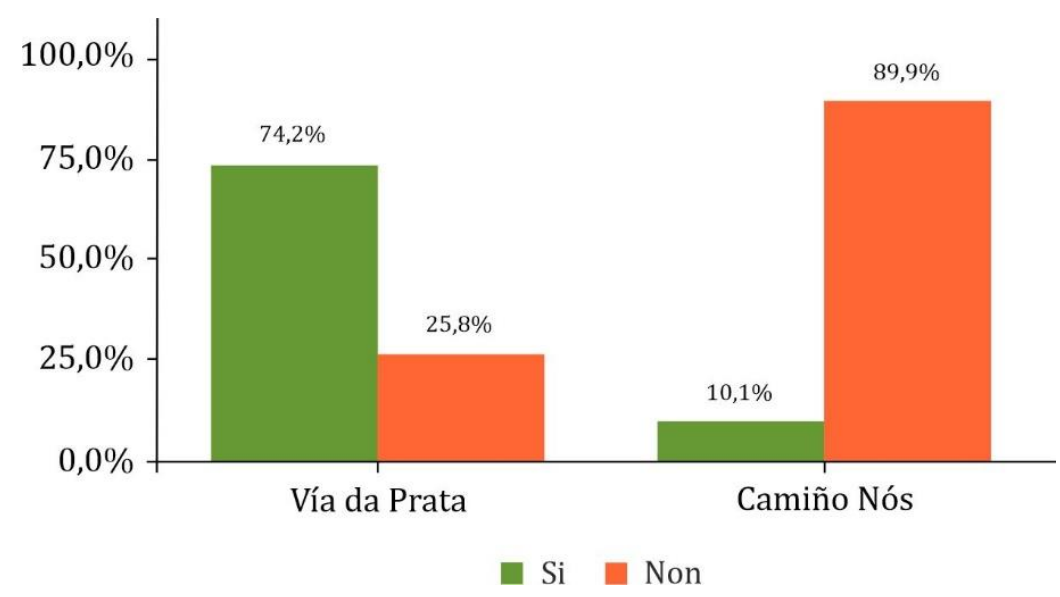

Figura 20. Coñecemento da Vía da Prata e do Camiño Nós (en \%). Fonte: elaboración propia..

Tras aplicar de novo o estatístico non paramétrico test chi-cadrado de Pearson para verificar se hai diferenzas significativas na mostra, no caso do coñecemento da Vía da Prata atópanse diferenzas significativas no da idade, sendo maior o coñecemento en todos os grupos agás no de 16 a 25 anos, que descoñecen esta ruta; e no da ocupación, sendo moito maior o coñecemento nos traballadores por conta allea que no resto de grupos.

No caso do Camiño Nós repítese o mesmo modelo, atopándose diferenzas significativas no seu coñecemento en función da idade e da ocupación. No caso da idade, este Camiño é máis coñecido nos segmentos máis novos (de 16 a 35 anos), e en canto á ocupación son os desempregados os que teñen maior coñecemento del.

Tras explicar brevemente a historia do Camiño Nós, o 57,9\% mostra interese en realizar esta variante do Camiño e en poder obter máis información nalgunha web (Táboa 11). Tras aplicar de novo o estatístico test chi-cadrado de Pearson, móstranse diferenzas no interese en realizar o Camiño e no xénero, mostrando maior predisposición as mulleres; na idade, estando máis interesados os máis novos (de 16 a 25 anos e de 46 a 55 anos); nos estudos, observándose un menor interese nos individuos con estudos secundarios; e na ocupación, maior interese nos traballadores, xa sexa por conta allea ou propia, e nos estudantes. No caso de obter máis información nunha páxina web non se atopan diferenzas significativas en función das variables sociodemográficas da mostra. 
Táboa 11. Interese en realizar o Camiño Nós e obter máis información nunha web (en \%). Escala Likert de 1 a 5 puntos

\begin{tabular}{clcc}
\hline & & $\begin{array}{c}\text { Intención realizar } \\
\text { Camiño Nós }\end{array}$ & $\begin{array}{c}\text { Interese en web con } \\
\text { información }\end{array}$ \\
\hline Válidos & 1 & 6,1 & 6,1 \\
& 2 & 4,5 & 4,5 \\
& 3 & 31,3 & 31,3 \\
4 & 26,8 & 26,8 \\
5 & 31,3 & 31,3 \\
& Total & 100,0 & 100,0 \\
\hline
\end{tabular}

Fonte: elaboración propia..

\section{Discusión e conclusións}

O Camiño de Santiago é un exemplo do apoxeo do turismo relixioso na época actual e do aproveitamento deste recurso como reclamo turístico para un territorio. A experiencia do Camiño vai máis aló da relixión, xa que aínda que a súa historia se remonta a unha tradición cristiá, na actualidade as motivacións dos individuos para emprender algunha das rutas que levan a Santiago son variadas. Deste estudo despréndese que, precisamente, a principal motivación non é a relixiosa, senón o lecer, seguida da experiencial e da espiritual. A relixión propiamente dita sitúase en cuarto lugar. Ademais, a experiencia do Camiño non se limita a realizalo, senón que os individuos buscan gozar da experiencia complementándoa con outros recursos que van atopando ao longo do seu percorrido, desde os recursos básicos como a gastronomía de cada zona e o aloxamento, a outros tipos de turismo, como a visita aos puntos de interese turístico próximos á ruta realizada, como museos e monumentos. 0 Camiño convértese, así, nunha viaxe turística cuxo trazado está marcado pola ruta elixida, pero que abarca moito máis que o seu percorrido.

Deste estudo despréndense tres grupos diferenciados de consumo en función da idade. Por unha parte, os máis novos (de 16 a 35 anos), con preferencia polo gozo da praia e costa, a visita a puntos de interese turístico, a visita a museos e monumentos, o lecer nocturno, as excursións e a gastronomía como complemento á experiencia. Ademais, alóxanse preferentemente en albergues ou en casas de amigos e familiares. Un segundo grupo de idade intermedia (de 36 a 54 anos), cunha maior preferencia polas compras, e con aloxamento predominante en albergue, aínda que neste grupo tamén se inclúen os hoteis de ata tres estrelas, as casas de amigos e familiares e incluso os cámpings. E, finalmente, un grupo sénior (maiores de 55 anos), interesado nunha experiencia máis relaxada, complementando o Camiño co enoturismo e co termalismo. Neste caso, a preferencia para o aloxamento son os hoteis de máis de tres estrelas e as casas rurais.

Outro resultado interesante deste estudo é a alta realización do Camiño por parte da mostra analizada, o 37,9\%, porcentaxe moi significativa, mostrando grande interese no territorio español por esta experiencia. Como dato relevante, tendo en conta a actual situación de pandemia mundial, este tipo de produto segue a ter demanda nestas circunstancias, cun $17,3 \%$ da mostra que realizou o Camiño no último ano, e máis concretamente o 10,7\% nos últimos seis meses. Verifícase tamén que o Camiño Francés é o máis elixido, sendo o primeiro Itinerario Cultural Europeo polo Consello de Europa en 1987. No caso dos que aínda non realizaron o Camiño, móstrase que o Camiño elixido cando emprendan esta aventura será o Camiño Francés na súa maioría, coincidindo co máis elixido polos que xa fixeron o Camiño. Así e todo, o Camiño Inglés, o segundo máis elixido polos que xa fixeron o Camiño, pasa ao último lugar como alternativa para os que aínda non o fixeron.

Cómpre mencionar tamén que, ao analizar as expectativas dos que aínda non realizaron o Camiño e o consumo real dos que si o realizaron, en todos os casos nos que hai diferenzas significativas (turismo 
de praia ou costa, enoturismo, relaxación, visita a parques naturais e termalismo), as expectativas de consumir ese tipo de turismo son máis altas que o consumo real durante o Camiño. Este comportamento dáse tamén noutros tipos de turismo, por exemplo no turismo de reunións, incentivos, convencións e exposicións (MICE, do inglés Meetings, Incentives, Conventions and Exhibitions), no que o turista, no seu imaxinario antes da viaxe, cre que realizará un maior consumo turístico e incluso máis gasto que o que realmente fai unha vez que está no destino (Araújo Vila, de Carlos Villamarín e Fraiz Brea, 2020). Ademais, á hora de formarse expectativas previas a unha viaxe, entra en xogo a memoria de experiencias anteriores. Co paso do tempo os elementos positivos dunha experiencia previa vólvense máis positivos, influíndo na creación de expectativas talvez maiores que a realidade (Jung e Cho, 2015). Antes de realizar calquera tipo de viaxe ou turismo os turistas buscan información, atopando a día de hoxe grandes cantidades (Björk e Kauppinen-Räisänen, 2015). Tal volume de información dá lugar a que se propoñan realizar gran cantidade de actividades ou visitas a recursos, o que na realidade non chega a ser posible en moitos dos casos.

No caso da cidade de Santiago de Compostela, propósito do Camiño de Santiago, o estudo de Murias e Rodríguez (2013) conclúe con que:

Os que acoden por primeira vez a esta cidade mostran unha inquietude por visitar museos e séntense atraídos polo feito de que o destino sexa unha cidade histórica, en cambio os que repiten visita buscan máis visitar familiares e amigos e séntense máis atraídos por estar en Santiago durante un Ano Santo, cambiando mesmo o tipo de consumo en función da vez que se visita o destino (Murias e Rodríguez, 2013, p. 62).

Centrándonos xa no Camiño Nós, un Camiño que non se atopa entre os doce principais, sorpréndenos que practicamente o $10 \%$ da mostra analizada teña certo coñecemento desta ruta, e especialmente que sexa coñecido pola xente nova, de entre 16 e 35 anos, sendo un Camiño vinculado aos compoñentes da Xeración Nós. Un dato moi positivo para o territorio polo que transcorre este Camiño é que, unha vez explicada a súa historia, máis da metade dos enquisados $(57,9 \%)$ mostran certo interese en realizar esta ruta, podendo así distribuír os peregrinos a Santiago en novas rutas do Camiño e aproveitándose así deste reclamo turístico un maior número de concellos galegos.

Como limitacións deste estudo, pode mencionarse o tamaño da mostra obtida, sendo estes uns primeiros resultados. En futuras investigacións recolleranse novas mostras e poderanse contrastar os resultados obtidos e verificar se a tendencia coincide coa obtida. A priori, os datos son positivos para o turismo vinculado ao Camiño, podendo os concellos que están no itinerario dalgúns dos Camiños beneficiarse dun produto maduro do territorio galego e un dos reclamos turísticos principais. 0 feito de ofrecer unha oferta complementaria ao Camiño en si é algo que os peregrinos reciben con grande agrado, de aí a oportunidade de traballar nunha estratexia turística que contemple este tipo de turistas/visitantes. Ademais, os enquisados están abertos a novas rutas, co que se poden beneficiar un maior número de concellos deste produto.

\section{Anexo. Enquisa}

\section{Estudo Camiño de Santiago}

Bos días/tardes. Desde a Universidade de Vigo estamos realizando un estudo sobre o consumo turístico durante a realización do Camiño de Santiago, así como do coñecemento dunha variante do Camiño, o Camiño Nós. Agradeceriámosche que dedicases cinco minutos a contestar esta enquisa. Os datos serán tratados de modo anónimo e confidencial. Moitas grazas pola túa participación.

Realizaches algunha vez o Camiño de Santiago?

$\square$ Si.

$\square$ Non. 
-RESPOSTAS NON FIXERON O CAMIÑO-

Tes intención de realizar o Camiño de Santiago?

Elixe do 1 ao 5.

$\square$ Non teño ningunha intención.

$\checkmark$ Estou totalmente seguro de que vou realizar o Camiño de Santiago.

En caso positivo, que che gustaría consumir durante a realización do Camiño, sendo 1 non teño ningunha intención de consumir e 5 sería o que máis consumirías:

$\square$ Ir de compras.

$\square$ Uso e gozo da praia/costa.

$\square$ Enoturismo (visita a bodegas...).

$\square$ Actividades de relaxación.

$\square$ Visita a destinos de interese turístico.

$\square$ Visita a museos e monumentos.

$\square$ Visita a parques naturais.

$\square$ Lecer nocturno.

$\square$ Excursións/visitas guiadas.

$\square$ Termalismo.

$\square$ Turismo gastronómico.

Que Camiño che gustaría facer?

$\square$ Camiño Francés.

$\square$ Camiño do Norte.

$\square$ Camiño Primitivo.

$\square$ Vía da Prata.

$\square$ Camiño Vasco.

$\square$ Camiño Portugués.

$\square$ Camiño Inglés.

$\square$ Camiño de Fisterra.

$\square$ Camiño Nós.

$\square$ Camiño de Inverno.

$\square$ Outro:

\author{
-RESPOSTAS SI FIXERON O CAMIÑO- \\ Que ruta realizaches? \\ $\square$ Camiño Francés. \\ $\square$ Camiño do Norte. \\ $\square$ Camiño Primitivo. \\ $\square$ Vía da Prata. \\ $\square$ Camiño Vasco. \\ $\square$ Camiño Portugués. \\ $\square$ Camiño Inglés. \\ $\square$ Camiño de Fisterra. \\ $\square$ Camiño Nós. \\ $\square$ Camiño de Inverno. \\ $\square$ Outro:
}

Canto hai que realizaches o Camiño? A última vez que o fixeras:

$\square$ No último mes.

$\square$ Nos últimos seis meses.

$\square$ No último ano.

$\square$ Nos últimos dous anos.

$\square$ Nos últimos cinco anos.

$\square$ Hai máis de cinco anos. 
Como realizaches o Camiño? A última vez que o fixeras:

$\square$ Andando.

$\square$ Bicicleta.

$\square$ Outro:

Nunha escala do 1 ao 5 , sendo 1 nada satisfactoria e 5 moi satisfactoria, como cualificarías a experiencia?

$\square$ Nada satisfactoria.

$\square$ Moi satisfactoria.

Nunha escala do 1 ao 5, cal é a túa intención de volver realizar o Camiño, sendo 1 completamente seguro de non realizalo e 5 completamente seguro de volver realizalo:

$\square$ Completamente seguro de non realizalo.

$\square$ Completamente seguro de volver realizalo.

Nunha escala do 1 ao 5, recomendaríaslles aos demais realizar o Camiño, sendo 1 non o recomendaría en absoluto e 5 recomendaríao totalmente:

$\square$ Non o recomendaría en absoluto.

$\square$ Recomendaríao totalmente.

Cantos días permaneciches en Galicia durante o Camiño? A última vez que o fixeras:

$\square$ Entre 1 e 2 días.

$\square$ Entre 2 e 4 días.

$\square$ Entre 4 e 7 días.

$\square$ Entre 7 e 10 días.

$\square$ Máis de 10 días.

Unha vez finalizado o Camiño, quedaches algún tempo máis en Galicia? (fóra da túa residencia habitual):

$\square \mathrm{Si}$.

$\square$ Non.

En caso positivo, cantos días?

Valora do 1 ao 5 os seguintes recursos que consumiches mentres realizaches o Camiño, sendo 1 non o consumín en absoluto e 5 é o que máis consumín:

$\square$ Ir de compras.

$\square$ Uso e gozo da praia/costa.

$\square$ Enoturismo (visita a bodegas...).

$\square$ Actividades de relaxación.

$\square$ Visita a destinos de interese turístico.

$\square$ Visita a museos e monumentos.

$\square$ Visita a parques naturais.

$\square$ Lecer nocturno.

$\square$ Excursións/visitas guiadas.

$\square$ Termalismo.

$\square$ Turismo gastronómico.

Cal foi a motivación para realizar o Camiño?

$\square$ Relixiosa.

$\square$ Espiritual.

$\square$ Lecer.

$\square$ Deportiva.

$\square$ Experiencial.

$\square$ Outra: 
Que é o que máis valoraches durante a realización do Camiño?

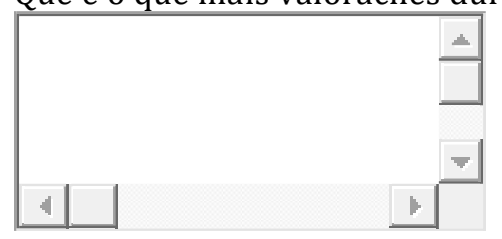

Onde te hospedaches mentres realizaches o Camiño?

$\square$ Hotel de ata tres estrelas.

$\square$ Hotel de máis de tres estrelas.

$\square$ Hotel balneario.

$\square$ Pensións.

$\square$ Vivendas de uso turístico ou vivendas turísticas.

$\square$ Apartamentos turísticos.

$\square$ Aloxamento rural.

$\square$ Cámping.

$\square$ Autocaravana.

$\square$ Casa de amigos/familiares.

$\square$ Albergue.

$\square$ Outro:

-VÍA DA PRATA E CAMIÑO NÓS-

Coñeces a Vía da Prata?

$\square \mathrm{Si}$.

$\square$ Non.

Coñeces o Camiño Nós?

$\square \mathrm{Si}$.

$\square$ Non.

En xuño de 1926, os membros da Xeración Nós, Javier Pardo, Ramón Otero Pedrayo, Vicente Risco, Lois Feixó, Monxardín e Antón Sánchez realizaron unha peregrinación desde Ourense a Santiago de Compostela. O trazado da viaxe quedou reflectido con detalle no relato "No Camiño de San-Yago", de Javier Pardo, que se publicou na revista A Nosa Terra. Considérase unha variante da Vía da Prata. Estarías interesado en facer este Camiño? Escala do 1 ao 5 :

$\square$ Totalmente desinteresado.

$\square$ Totalmente interesado.

Gustaríache poder acceder a unha web onde obter máis información deste Camiño? Escala do 1 ao 5:

$\square$ Non me interesaría en absoluto.

$\square$ Estaría moi interesado.

-PERFIL SOCIODEMOGRÁFICO-

Xénero:

$\square$ Feminino.

$\square$ Masculino.

Idade:

16-25 anos.

$\square$ 26-35 anos.

$\square$ 36-45 anos.

$\square$ 46-55 anos.

$\square$ 56-65 anos.

$\square$ Máis de 65 anos. 
Nivel de estudos:

$\square$ Básicos (ata graduado, ESO, EXB).

$\square$ Secundarios (BUP, COU, bacharelato, FP).

$\square$ Superiores (estudos universitarios).

País de residencia:

Se é España, provincia de residencia:

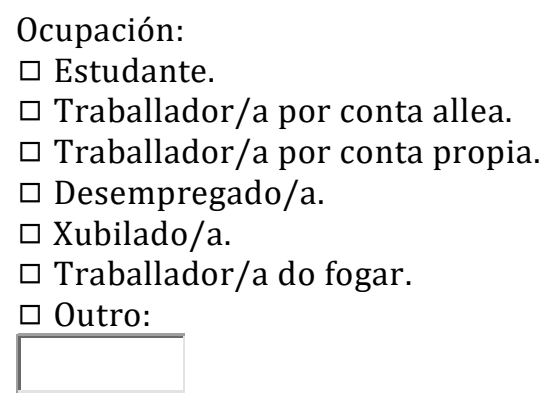

\section{Autoría do traballo}

Conceptualización, N.A.V. e J.A.F.B.; metodoloxía, N.A.V. e D.R.T.; adquisición de datos, N.A.V.; análise e interpretación, N.A.V e J.A.F.B.; redacción e preparación do borrador, N.A.V.; redacción, revisión e edición, N.A.V e D.R.T. Todos os autores leron e están de acordo coa versión publicada do manuscrito.

\section{Bibliografía}

Amaro, S., Antunes, A., e Henriques, C. (2018). A closer look at Santiago de Compostela's pilgrims through the lens of motivations. Tourism Management, 64, 271-280. DOI: https://doi.org/10.1016/j.tourman.2017.09.007

Andrade, M. J., e Caamaño, I. C. (2016). La imagen del Camino de Santiago: análisis de su representación promocional como producto turístico. Tourism \& Management Studies, 12(2), 38-46. DOI: https://doi.org/10.18089/tms.2016.12205

Araújo Vila, N., de Carlos Villamarín, P., e Fraiz Brea, J. A. (2020). Expectativas previas y valoración tras la asistencia a un evento MICE. Estudio de caso de las XXV Jornadas Hispanolusas de Gestión Científica. Lurralde: Investigación y Espacio, 43, 459-484.

Recuperado de: https://dialnet.unirioja.es/servlet/articulo?codigo=7246672

Björk, P., e Kauppinen-Räisänen, H. (2015). Contemporary insights to the dynamic pre-trip information sourcing behaviour. Tourism and Hospitality Research, 15(1), 39-53. DOI: https://doi.org/10.1177/1467358414553871

Cazaux, F. (2011). To be a pilgrim: A contested identity on Saint James' Way. Tourism: An International Interdisciplinary Journal, 59(3), 353-367. Recuperado de: https://hrcak.srce.hr/74038

Chaspoul, C., e Lunven, M. (1993). Tourisme religieux. Paris, France: Touristiques Européennes.

Coleman, S., e Elsner, J. (1995). Pilgrimage: Past and present in the world religions. Cambridge, MA: Harvard University Press.

Collins-Kreiner, N., e Kliot, N. (2000). Pilgrimage tourism in the Holy Land: The behavioural characteristics of Christian pilgrims. GeoJournal, 50(1), 55-67.

Eade, J. (2016). Parish and pilgrimage in a changing Europe. En D. Pasura e M. Bivand Erdal (Eds.), Migration, transnationalism and catholicism (pp. 75-92). London, UK: Palgrave Macmillan.

DOI: https://doi.org/10.1057/978-1-137-58347-5 
Federación Española de Asociaciones de Amigos del Camino de Santiago. (2020). Un camino más que llega a Compostela, el Camino de Nós. Logroño: Federación Española de Asociaciones de Amigos del Camino de Santiago.

Recuperado de: https://www.caminosantiago.org/cpperegrino/prensa/verprensa.asp?PrensaID=15489

Fernández, E. M., e Naranjo, L. M. P. (2010). El turismo religioso: estudio del Camino de Santiago. Gestión Turística, 13, 9-36. Recuperado de: https://dialnet.unirioja.es/servlet/articulo?codigo=3744671

Fernández-Poyatos, M. D., Aguirregoitia Martínez, A., e Boix Martínez, B. (2011). Camino de Santiago y Xacobeo 2010 en los portales turísticos de las comunidades autónomas. Revista Latina de Comunicación Social, 67, 23-46. DOI: https://doi.org/10.4185/RLCS-67-946-023-046

GalicianRoots. (2020). https://www.galicianroots.com/

Gigirey, A. (2003). Turismo cultural en espacios sagrados desde la perspectiva de los residentes. Un estudio de la Catedral de Santiago de Compostela. Estudios Turísticos, 158, 79-108.

Recuperado de: https://dialnet.unirioja.es/servlet/articulo?codigo=2162789

Gracia, J. (2005). El Camino de Santiago en el nuevo milenio. Fayuela: Revista de Estudios Calceatenses, 1, 57-66. Recuperado de: https://dialnet.unirioja.es/servlet/articulo?codigo=1394328

Granero, A., Ruiz, F., e García, M. E. (2005). El Camino de Santiago como sendero de gran recorrido en la naturaleza. Efdeportes, 10(87). Recuperado de: https://www.efdeportes.com/efd87/camino.htm

Herrero, A. G. (2009). Madrid 1809-2009: dos centurias de la actual Real Iglesia Parroquial de Santiago y San Juan Bautista. Peregrino: Revista del Camino de Santiago, 123, 38-39.

IGE. (2016). Encuesta sobre el turismo en destino de Galicia. Santiago de Compostela: Instituto Galego de Estatística. Recuperado de:

https://www.ige.eu/web/mostrar ficha actividad.jsp?idioma=es\&paxina=004005001\&origen=org\&operacio $\underline{\mathrm{n}=137}$

Jung, D., e Cho, M.-H. (2015). A discovery of the positive travel experience in pre-trip, on-site and post-trip stage. Amherts, MA: University of Massachusetts Amherst.

Recuperado de: https://scholarworks.umass.edu/cgi/viewcontent.cgi?article=1052\&context=ttra

Kim, B., Kim, S., e King, B. (2020). Religious tourism studies: Evolution, progress, and future prospects. Tourism Recreation Research, 45(2), 185-203. DOI: https://doi.org/10.1080/02508281.2019.1664084

Lanczkowski, G. (1982). Die heilige Reise: auf den Wegen von Göttern und Menschen. Freiurg/Basel/Wien, Germany: Herder.

Leira, J., Rego, G., e Santos, M. P. (2010). Peregrinaciones y turismo. El Camino de Santiago. Revista de Ocio y Turismo (Rotur), 3, 39-48.

Lois González, R. C. (2013). The Camino de Santiago and its contemporary renewal: Pilgrims, tourists and territorial identities. Culture and Religion, 14(1), 8-22. DOI: https://doi.org/10.1080/14755610.2012.756406

Lois González, R. C., e López, L. (2015). El origen del turismo viajero italiano a lo largo del Camino de Santiago. Investigaciones Turísticas, 9, 132-159. DOI: http://dx.doi.org/10.14198/inturi2015.9.06

Malhotra, N. K. (2004). Investigación de mercados. Un enfoque aplicado (4 ed.). Naucalpan de Juárez, México: Pearson Eduación de México.

Martín-Duque, C. (2017). Los impactos del turismo en el Camino de Santiago Francés: una aproximación cualitativa. Methaodos. Revista de Ciencias Sociales, 5(1), 62-73. DOI: http://dx.doi.org/10.17502/m.rcs.v5i1.155

Martínez Roget, F., Castro Domínguez, M. N., e Fraiz Brea, J. A. (2018). O turismo como fonte de riqueza en Galicia: Análise dalgunhas experiencias. Revista Galega de Economía, 27(3), 65-80.

DOI: https://doi.org/10.15304/rge.27.3.5437

McKelvie, J. (2005). Religious tourism. Travel \& Tourism Analyst, 4, 1-47.

Moulin-Stożek, D. (2019). Pilgrims' play on the Santiago Way. International Journal of Religious Tourism and Pilgrimage, 7(5), 24-32. DOI: http://doi.org/10.21427/ZFQ1-XQ84

Mróz, F., Mróz, Ł., e Krogmann, A. (2019). Actors conditioning the creation and development of a network of Camino de Santiago routes in Visegrád Group countries. International Journal of Religious Tourism and Pilgrimage, 7(5), 56-71. DOI: http://doi.org/10.21427/x89p-6r88

Murias Fernández, M. P., e Rodríguez González, D. R. (2014). De novo en Santiago de Compostela: as implicacións da lealdade para un destino turístico. Revista Galega de Economía, 23(2), 47-67. DOI: https://doi.org/10.15304/rge.27.3.5437

Nicolaides, A. (2016). Marian tourism: Eastern orthodox and roman catholic pilgrimage. African Journal of Hospitality, Tourism and Leisure, 5(4), 1-19. Recuperado de: http://hdl.handle.net/10500/22737

Nolan, M. L., e Nolan, S. (1992). Religious sites as tourism attractions in Europe. Annals of Tourism Research, 19(1), 68-78. DOI: https://doi.org/10.1016/0160-7383(92)90107-Z 
Olsen, D. H., e Guelke, J. K. (2004). 'Nourishing The Soul': Geography and matters of meaning. En D.G. Janelle, B. Warf e K. Hansen (Eds.), WorldMinds: Geographical perspectives on 100 problems (pp. 595-599). Dordrecht, Germany: Springer. DOI: https://doi.org/10.1007/978-1-4020-2352-1 97

Otero, F. A. (2009). Santiago y los Caminos de Santiago: un paisaje cultural, una cultura del paisaje. Boletín de la Asociación de Geógrafos Españoles, 51, 203-218.

Recuperado de: https://dialnet.unirioja.es/servlet/articulo?codigo=3095237

Pardo, J. (1926-1927). No Camiño de San-Yago. A Nosa Terra (varios números).

Pilgrim. (2020). https://www.pilgrim.es/

Pinal, S. (05/01/2020). Diez concellos impulsan el Camino de la Xeración Nós. La Región. Recuperado de: https://www.laregion.es/articulo/o-carballinho/diez-concellos-impulsan-camino-xeracionnos/20200104221049917165.html

Porcal, M. C. (2006). Turismo cultural y turismo religioso y peregrinaciones en Navarra. Las Javieradas como caso de estudio. Cuadernos de Turismo, 18, 103-134.

Recuperado de: https://revistas.um.es/turismo/article/view/17831/0

Poutet, H. (2000). Le pélerinage à Saint-Jacques de Compostelle. Bulletin d'Histoire Contemporaine de l'Espagne (2nd ed.), 30, 227-242.

Raj, R., e Griffin, K. A. (Eds.). (2015). Religious tourism and pilgrimage management: An international perspective (2nd Edition). Cabi.

Rejman, K., Maziarz, P., Kwiatkowski, C. A., e Haliniarz, M. (2016). Religious tourism as a tourism product. World Scientific News, (57), 562-575.

Rinschede, G. (1990). Religious tourism. Geographische Rundschau, 42(1), 14-20.

Rinschede, G. (1992). Forms of religious tourism. Annals of Tourism Research, 19(1), 51-67. DOI:https://doi.org/10.1016/0160-7383(92)90106-Y

Ron, A. S. (2009). Towards a typological model of contemporary Christian travel. Journal of Heritage Tourism, 4(4), 287-297. DOI: https://doi.org/10.1080/17438730903045548

Roussel, R. (1972). Les pèlerinages. Paris, France: FeniXX.

Sánchez-Carretero, C. (2012). Heritage regimes and the Camino de Santiago: Gaps and logics. En R. F. Bendix, A. Eggert e A. Peselmann (Eds.), Heritage regimes and the state (pp. 141-155). Göttingen Studies in Cultural Property, 6. Göttingen, Germany: Universitätasverlag Göttingen.

Recuperado de: https://digital.csic.es/bitstream/10261/98670/1/heritage regimes Sanchez.pdf

Santos, X. M. (2006). El Camino de Santiago: turistas y peregrinos hacia Compostela. Cuadernos de Turismo, 18, 135-150. Recuperado de: http://revistas.um.es/turismo/article/view/17791

Santos, X. M., e Lois González, R. C. (2011). El Camino de Santiago en el contexto de los nuevos turismos. Estudios Turísticos, 189, 95-116. Recuperado de: $\underline{\text { https://dialnet.unirioja.es/servlet/articulo?codigo=3898981 }}$

Shinde, K. A. (2010). Entrepreneurship and indigenous enterpreneurs in religious tourism in India. International Journal of Tourism Research, 12(5), 523-535. DOI: https://doi.org/10.1002/jtr.771

Smith, V. L. (1992). The quest in guest. Annals of Tourism Research, 19(1), 1-17. DOI: https://doi.org/10.1016/0160-7383(92)90103-V

Somoza, X., e Lois González, R. C. (2017). Ordenación del territorio y estrategias de planificación en los Caminos de Santiago Patrimonio Mundial. Investigaciones Geográficas, 68, 47-63.

DOI: $\underline{\text { http://dx.doi.org/10.14198/INGE02017.68.03 }}$

Turgalicia. (2020). https://www.turismo.gal/inicio

Vukonić, B. (1996). Tourism and religion. Bingley, UK: Emerald.

Wang, T., Luo, Y., \& Tang, L. R. (2015). The investigation of consumer motivations to patronize boutique hotels using push-pull theory: A case study in Xiamen, China. International Journal of Tourism Cities, 1(4), 317-328. DOI: https://doi.org/10.1108/IJTC-08-2014-0010

Wang, W., Chen, J. S., e Huang, K. (2016). Religious tourist motivation in Buddhist Mountain: The case from China. Asia Pacific Journal of Tourism Research, 21(1), 57-72.

DOI: https://doi.org/10.1080/10941665.2015.1016443 